\title{
LEVEL II SCOUR ANALYSIS FOR BRIDGE 46 (CHESVT00110046) on STATE ROUTE 11, crossing the MIDDLE BRANCH WILLIAMS RIVER, CHESTER, VERMONT
}

U.S. Geological Survey Open-File Report 97-365

Prepared in cooperation with

VERMONT AGENCY OF TRANSPORTATION and

FEDERAL HIGHWAY ADMINISTRATION 


\section{LEVEL II SCOUR ANALYSIS FOR BRIDGE 46 (CHESVT00110046) on STATE ROUTE 11, crossing the MIDDLE BRANCH WILLIAMS RIVER, CHESTER, VERMONT \\ By EMILY C. WILD}

U.S. Geological Survey Open-File Report 97-365

Prepared in cooperation with

VERMONT AGENCY OF TRANSPORTATION

and

FEDERAL HIGHWAY ADMINISTRATION

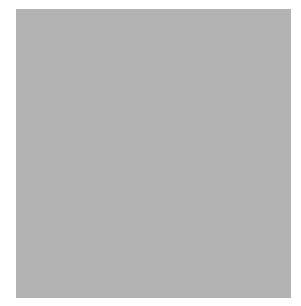




\title{
U.S. DEPARTMENT OF THE INTERIOR BRUCE BABBITT, Secretary
}

\author{
U.S. GEOLOGICAL SURVEY \\ Gordon P. Eaton, Director
}

For additional information write to:

District Chief

U.S. Geological Survey 361 Commerce Way

Pembroke, NH 03275-3718
Copies of this report may be purchased from:

U.S. Geological Survey

Branch of Information Services

Open-File Reports Unit

Box 25286

Denver, CO 80225-0286 


\section{CONTENTS}

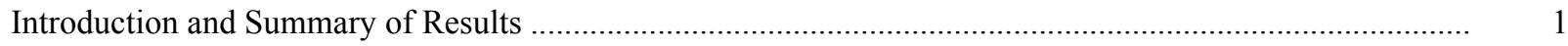

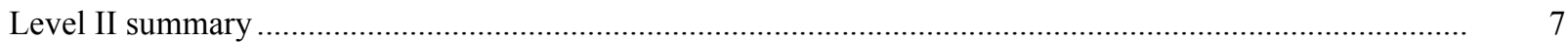

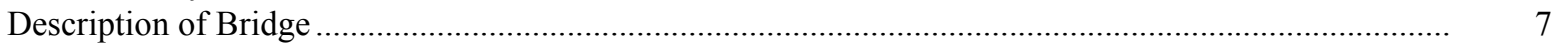

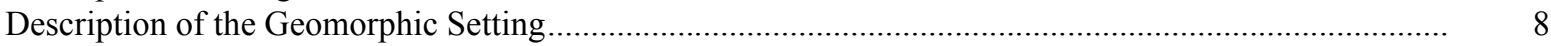

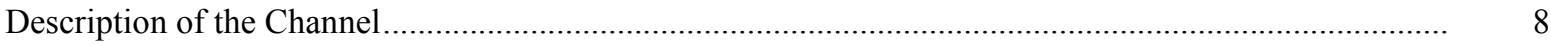

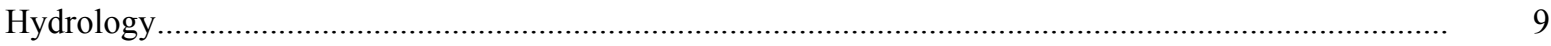

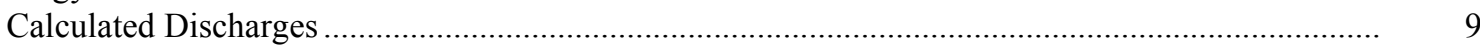

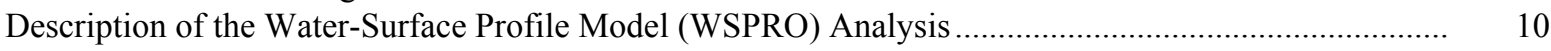

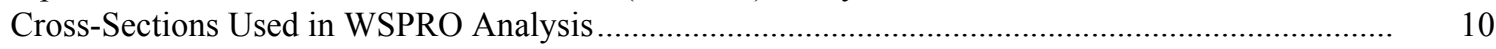

Data and Assumptions Used in WSPRO Model ...................................................................... 11

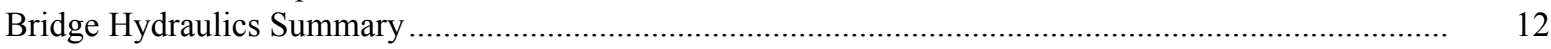

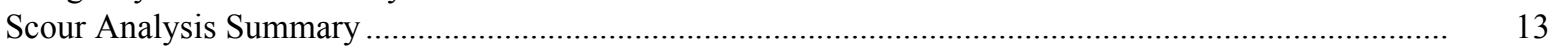

Special Conditions or Assumptions Made in Scour Analysis ...................................................... 13

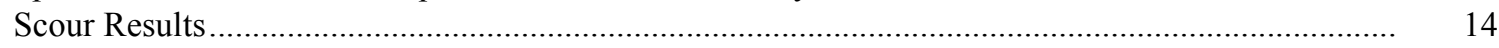

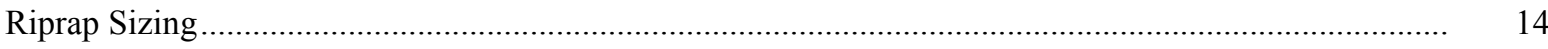

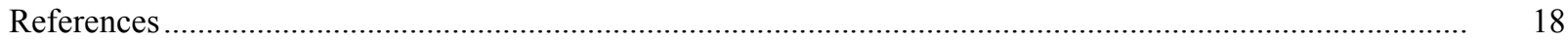

Appendixes:

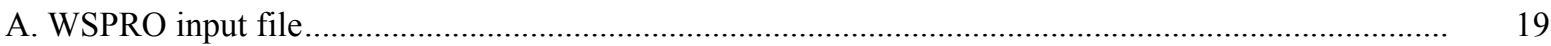

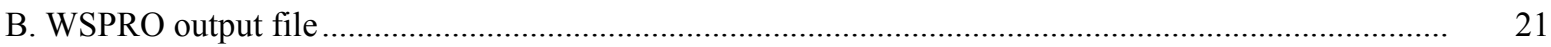

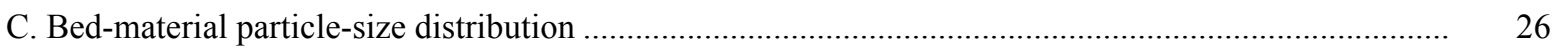

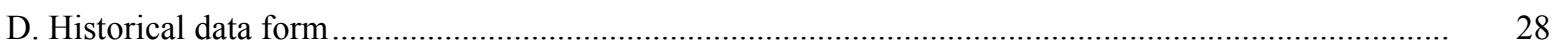

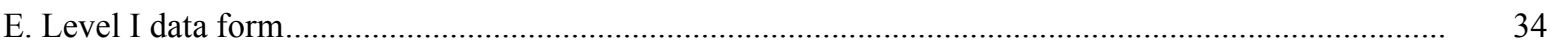

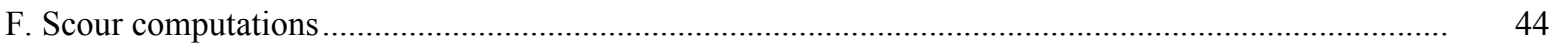

\section{FIGURES}

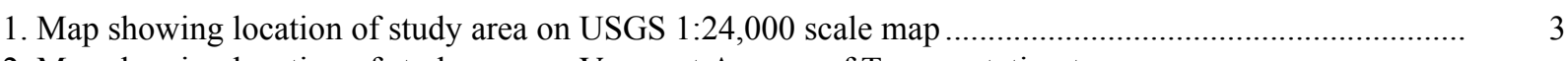

2. Map showing location of study area on Vermont Agency of Transportation town

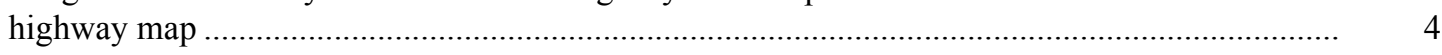

3. Structure CHESVT00110046 viewed from upstream (September 12, 1996) .........................................

4. Downstream channel viewed from structure CHESVT00110046 (September 12, 1996)....................... 5

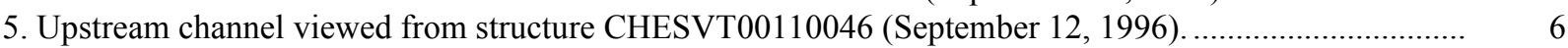

6. Structure CHESVT00110046 viewed from downstream (September 12, 1996)................................... 6

7. Water-surface profiles for the 100- and 500-year discharges at structure

CHESVT00110046 on State Route 11, crossing the Middle Branch Williams River,

Chester, Vermont..

8. Scour elevations for the 100- and 500-year discharges at structure

CHESVT00110046 on State Route 11, crossing the Middle Branch Williams River,

Chester, Vermont.

\section{TABLES}

1. Remaining footing/pile depth at abutments for the 100-year discharge at structure

CHESVT00110046 on State Route 11, crossing the Middle Branch Williams River,

Chester, Vermont

2. Remaining footing/pile depth at abutments for the 500-year discharge at structure

CHESVT00110046 on State Route 11, crossing the Middle Branch Williams River,

Chester, Vermont 


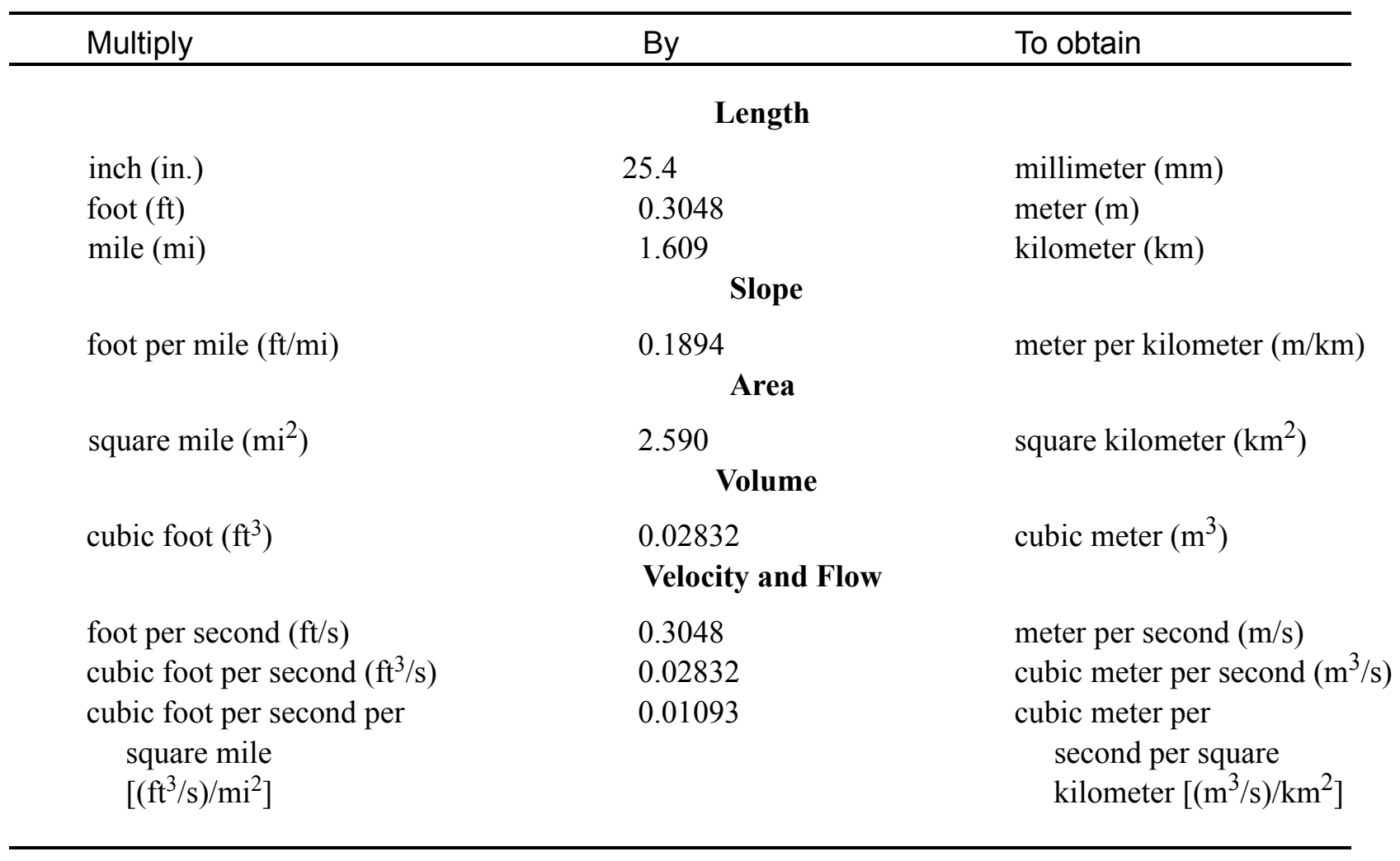

\section{OTHER ABBREVIATIONS}

$\begin{array}{lrlr}\mathrm{BF} & \text { bank full } & \text { LWW } & \text { left wingwall } \\ \mathrm{cfs} & \text { cubic feet per second } & \text { MC } & \text { main channel } \\ \mathrm{D}_{50} & \text { median diameter of bed material } & \text { RAB } & \text { right abutment } \\ \mathrm{DS} & \text { downstream } & \text { RABUT } & \text { face of right abutment } \\ \mathrm{elev} & \text { elevation } & \text { RB } & \text { right bank } \\ \mathrm{f} / \mathrm{p} & \text { flood plain } & \text { ROB } & \text { right overbank } \\ \mathrm{ft}^{2} & \text { square feet } & \text { RWW } & \text { right wingwall } \\ \mathrm{ft} / \mathrm{ft} & \text { feet per foot } & \text { TH } & \text { town highway } \\ \mathrm{JCT} & \text { junction } & \text { UB } & \text { under bridge } \\ \mathrm{LAB} & \text { left abutment } & \text { US } & \text { upstream } \\ \mathrm{LABUT} & \text { face of left abutment } & \text { USGS } & \text { United States Geological Survey } \\ \mathrm{LB} & \text { left bank } & \text { VTAOT Vermont Agency of Transportation } \\ \mathrm{LOB} & \text { left overbank } & \text { WSPRO } & \text { water-surface profile model }\end{array}$

In this report, the words "right" and "left" refer to directions that would be reported by an observer facing downstream. Sea level: In this report, "sea level" refers to the National Geodetic Vertical Datum of 1929-- a geodetic datum derived from a general adjustment of the first-order level nets of the United States and Canada, formerly called Sea Level Datum of 1929.

In the appendices, the above abbreviations may be combined. For example, USLB would represent upstream left bank. 


\title{
LEVEL II SCOUR ANALYSIS FOR BRIDGE 46 (CHESVT00110046) ON STATE ROUTE 11, CROSSING THE MIDDLE BRANCH WILLIAMS RIVER, CHESTER, VERMONT
}

\author{
By Emily C. Wild
}

\section{INTRODUCTION AND SUMMARY OF RESULTS}

This report provides the results of a detailed Level II analysis of scour potential at structure CHESVT00110046 on State Route 11 crossing the Middle Branch Williams River, Chester, Vermont (figures 1-8). A Level II study is a basic engineering analysis of the site, including a quantitative analysis of stream stability and scour (U.S. Department of Transportation, 1993). Results of a Level I scour investigation also are included in Appendix E of this report. A Level I investigation provides a qualitative geomorphic characterization of the study site. Information on the bridge, gleaned from Vermont Agency of Transportation (VTAOT) files, was compiled prior to conducting Level I and Level II analyses and is found in Appendix D.

The site is in the Green Mountain and New England Upland sections of the New England physiographic province in southeastern Vermont. The $28.0-\mathrm{mi}^{2}$ drainage area is in a predominantly rural and forested basin. In the vicinity of the study site, the surface cover is forested on the upstream left and downstream right overbanks. The upstream right and downstream left overbanks are pasture while the immediate banks have dense woody vegetation.

In the study area, the the Middle Branch Williams River has an incised, sinuous channel with a slope of approximately $0.013 \mathrm{ft} / \mathrm{ft}$, an average channel top width of $81 \mathrm{ft}$ and an average bank height of $11 \mathrm{ft}$. The channel bed material ranges from gravel to bedrock with a median grain size $\left(\mathrm{D}_{50}\right)$ of $70.7 \mathrm{~mm}(0.232 \mathrm{ft})$. The geomorphic assessment at the time of the Level I and Level II site visit on September 12, 1996, indicated that the reach was stable.

The State Route 11 crossing of the Middle Branch Williams River is a 118-ft-long, two-lane steel stringer type bridge consisting of a 114-foot steel plate deck (Vermont Agency of Transportation, written communication, March 29, 1995). The opening length of the structure parallel to the bridge face is $109 \mathrm{ft}$.The bridge is supported by vertical, concrete abutments with wingwalls. The channel is skewed approximately 45 degrees to the opening while the opening-skew-to-roadway is 50 degrees. 
A scour hole $2 \mathrm{ft}$ deeper than the mean thalweg depth was observed 128 feet downstream during the Level I assessment. Type-1 (less than 1 foot) stone fill protects the downstream right wingwall. Type-2 (less than $3 \mathrm{ft}$ diameter) stone fill protects the upstream right wingwall, the left and right abutments, the upstream left and right road embankments. Additional details describing conditions at the site are included in the Level II Summary and Appendices D and E.

Scour depths and recommended rock rip-rap sizes were computed using the general guidelines described in Hydraulic Engineering Circular 18 (Richardson and others, 1995). Total scour at a highway crossing is comprised of three components: 1) long-term streambed degradation; 2) contraction scour (due to accelerated flow caused by a reduction in flow area at a bridge) and; 3 ) local scour (caused by accelerated flow around piers and abutments). Total scour is the sum of the three components. Equations are available to compute depths for contraction and local scour and a summary of the results of these computations follows.

There was no computed contraction scour for any modelled flows. Abutment scour ranged from 7.0 to $10.3 \mathrm{ft}$. The worst-case abutment scour occurred at the 500-year discharge. Additional information on scour depths and depths to armoring are included in the section titled "Scour Results". Scoured-streambed elevations, based on the calculated scour depths, are presented in tables 1 and 2. A cross-section of the scour computed at the bridge is presented in figure 8 . Scour depths were calculated assuming an infinite depth of erosive material and a homogeneous particle-size distribution.

It is generally accepted that the Froehlich equation (abutment scour) gives "excessively conservative estimates of scour depths" (Richardson and others, 1995, p. 47). Usually, computed scour depths are evaluated in combination with other information including (but not limited to) historical performance during flood events, the geomorphic stability assessment, existing scour protection measures, and the results of the hydraulic analyses. Therefore, scour depths adopted by VTAOT may differ from the computed values documented herein. 


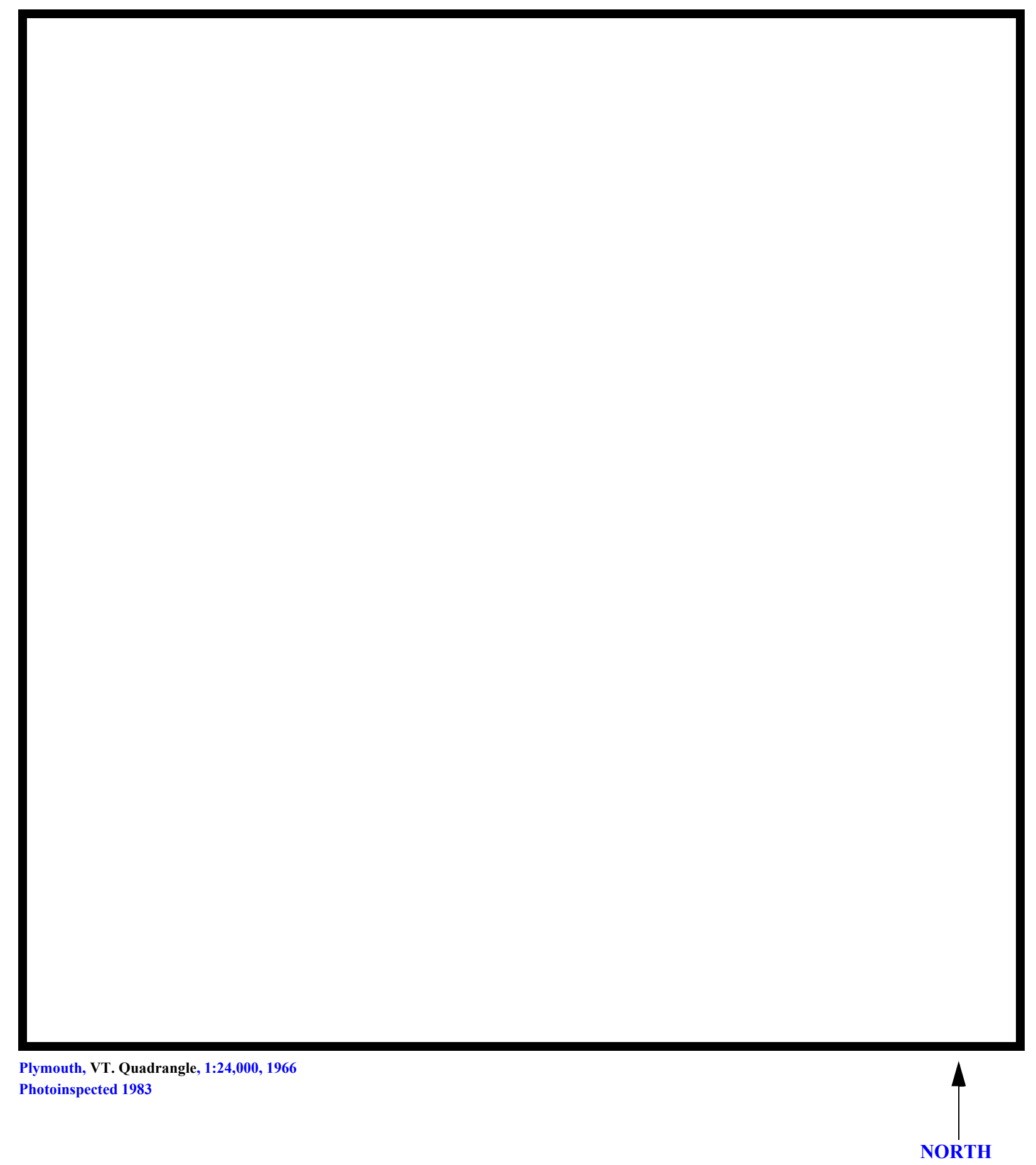

Figure 1. Location of study area on USGS 1:24,000 scale map. 
Figure 2. Location of study area on Vermont Agency of Transportation town highway map. 

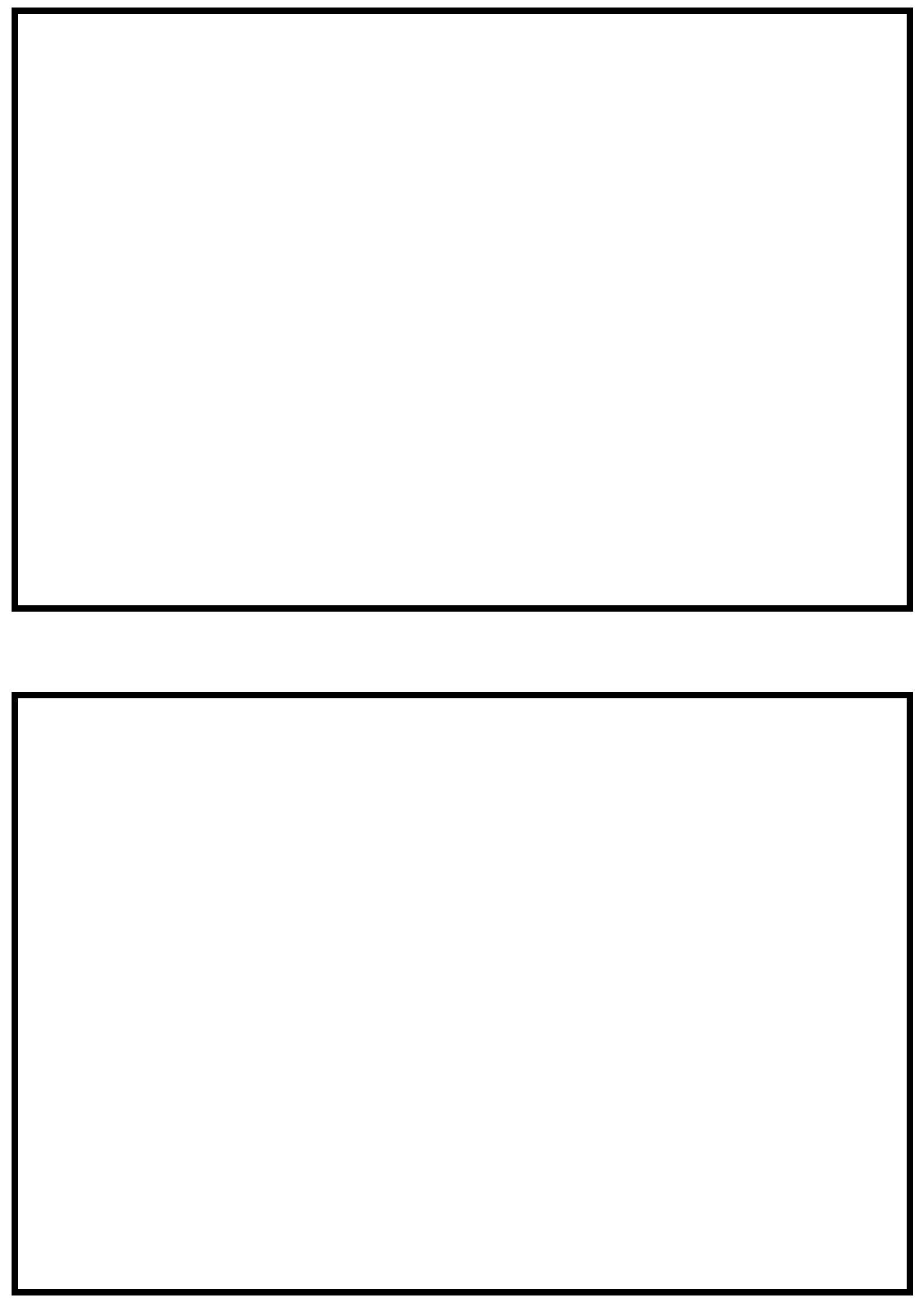

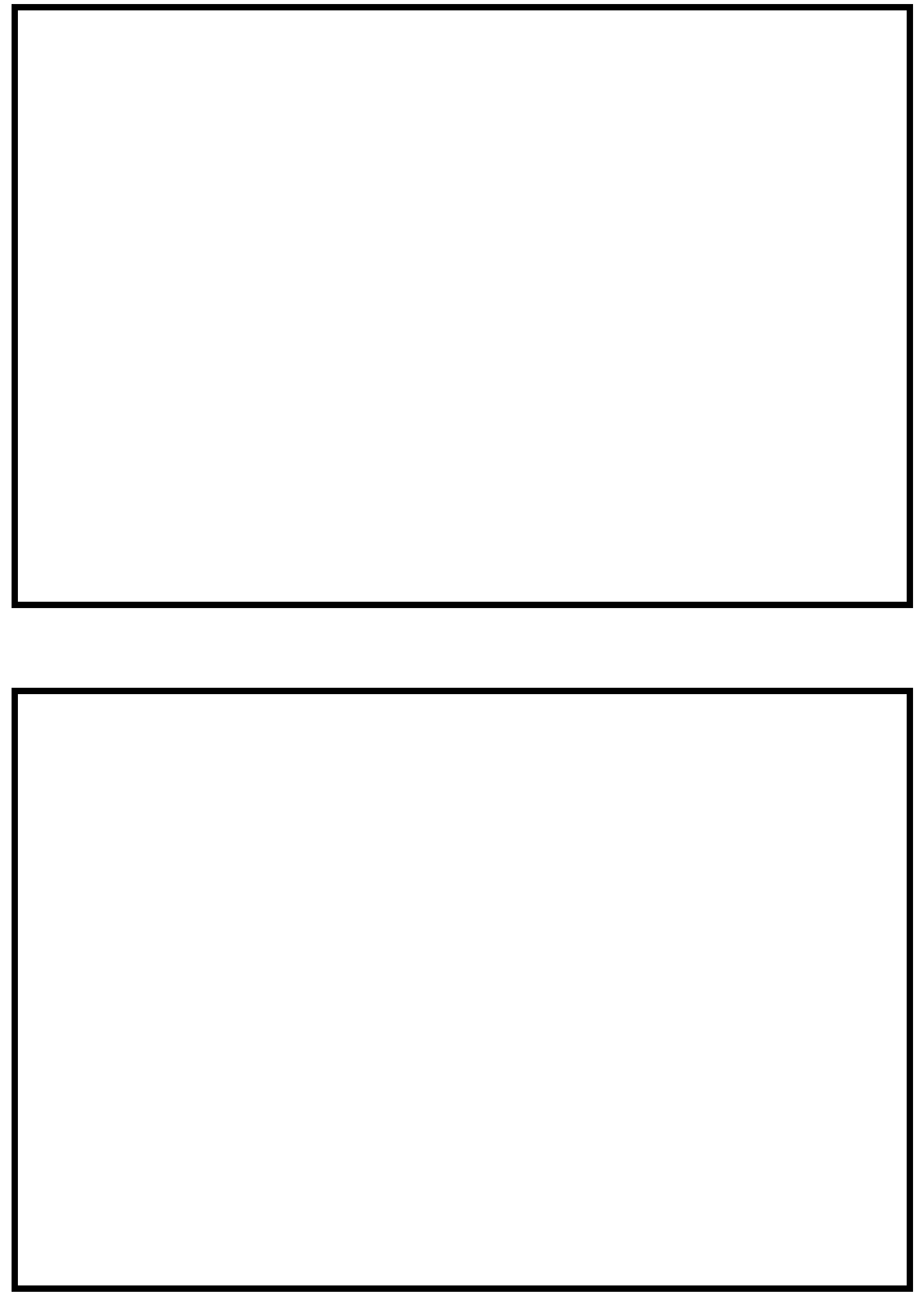


\section{LEVEL II SUMMARY}

\begin{tabular}{llllll} 
Structure Number & CHESVT00110046 & & \multicolumn{3}{c}{ Middle Branch Williams River } \\
Stream & Road & VT 11 & District & 2
\end{tabular}

\section{Description of Bridge}

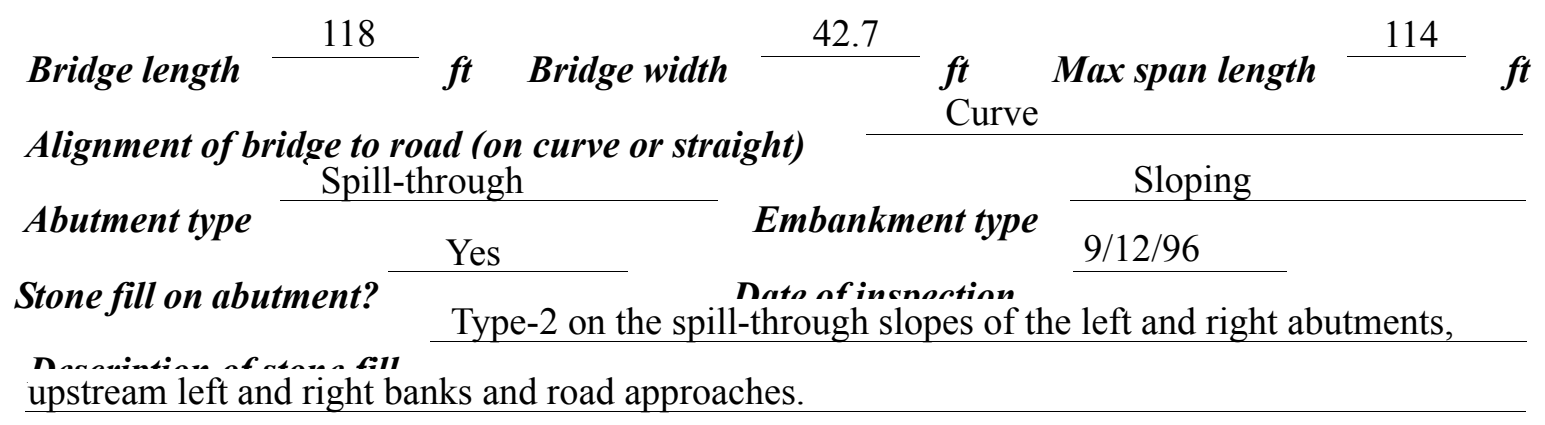

Abutments and wingwalls are concrete. In front of the concrete abutments, type- 2 stone fill has been placed to create spill-through slopes.

\begin{tabular}{l}
\hline Is bridge skewed to flood flow according to $\mathrm{Y} \quad$ 'survey? \\
There is a moderate channel bend in the downstream reach. The scour hole has developed in the \\
location where the bedrock controlled bend is present 150 feet downstream of bridge
\end{tabular}

Debris accumulation on bridge at time of Level I or Level II site visit:

\begin{tabular}{|c|c|c|c|}
\hline & $\begin{array}{c}\text { Date af insnortion } \\
9 / 12 / 96 \\
\end{array}$ & $\begin{array}{l}\text { Percent of olmmual } \\
\text { blocked inortzontatly }\end{array}$ & $\begin{array}{l}\text { Percent of a n wel....el } \\
\text { blocked verticatty }\end{array}$ \\
\hline Level I & $9 / 12 / 96$ & 0 & 0 \\
\hline I ovel II & Moderate. & & \\
\hline
\end{tabular}

The assessment of 9/12/96 noted a large bend in the channel, approximately 150 feet Doscriho any foaturos noar ar at tho hridoo that mav, affort flow, (includo ahsorvation datol downstream from the bridge. Also at this location, the channel and right bank is predominately

bedrock. 


\section{Description of the Geomorphic Setting}

General topography The channel is located within a moderately steep valley, with narrow, irregular flood plains.

Geomorphic conditions at bridge site: downstream (DS), upstream (US)

Date of inspection $\quad 9 / 12 / 96$

DS left: $\quad$ Steep channel bank to a narrow terrace

DS right: $\quad$ Steep valley wall

US left: $\quad$ Steep valley wall

US right: $\quad$ Moderately sloped overbank with a narrow terrace

\section{Description of the Channel}

\begin{tabular}{|c|c|c|c|}
\hline & 81 & & 11 \\
\hline Average top width & $\stackrel{\boldsymbol{f t}}{\text { Cobbles/ Gravel }}$ & Average depth & Gravel/Sand \\
\hline
\end{tabular}

Predominant bed material Bank material Sinuous but stable

with semi-allúvial channel boundaries and a narrow flood plain.

$9 / 12 / 96$

Vegetative co 1 Grass and Vermont State Route 11

DS left: $\quad$ Trees

DS right: $\quad$ Trees and brush

US left: $\quad$ Grass and Vermont State Route 11

US right: $\quad$ Y

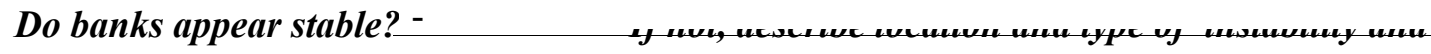

date of observation.

None. 9/12/97

Describe any obstructions in channel and date of observation. 


\section{Hydrology}

Drainage area $\stackrel{28.0}{\longrightarrow} \mathrm{mi}^{2}$

Percentage of drainage area in physiographic provinces: (approximate)

Physiographic province/section

New England/ Green Mountain

New England/ New England Upland
Percent of drainage area 85

15

Is drainage area considered rural or urban? — Rural _ Describe any significant urbanization:

Is there a USGS gage on the stream of interest?

No

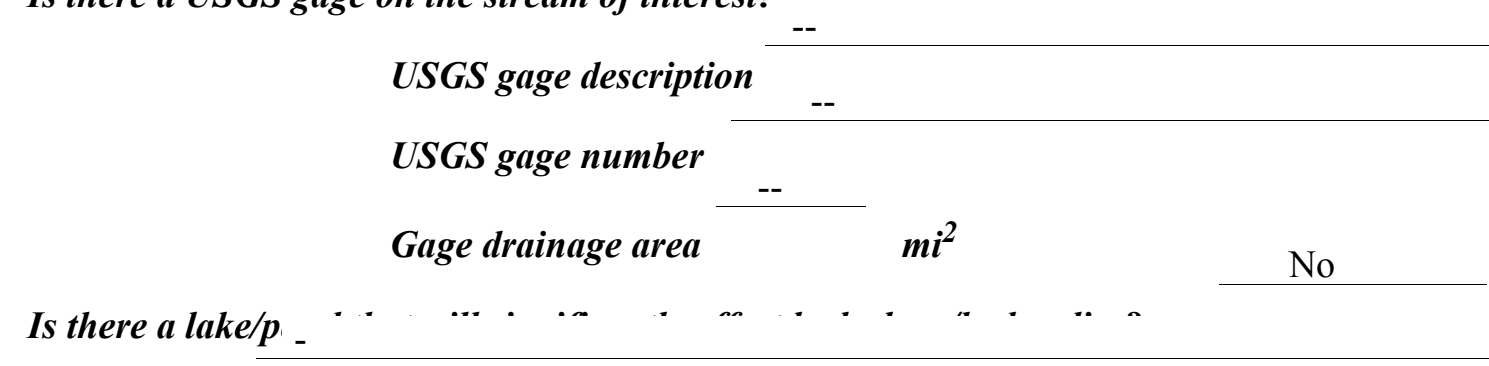

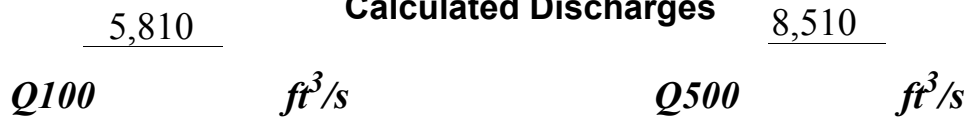

The 100- and 500-year discharges are based on a

drainage area relationship.[(28.0/33.5)exp 0.68] with Federal Insurance Study discharge values at the Lovers Lane Brook confluence (Federal Emergency Management Agency, 1982). Lovers Lane Brook enters the Middle Branch Williams River downstream of this site. The values computed are within a range defined by several empirical flood frequency curves (Benson, 1962; Johnson and Tasker, 1974; FHWA, 1983; Potter, 1957a\&b; Talbot, 1887). 


\section{Description of the Water-Surface Profile Model (WSPRO) Analysis}

Datum for WSPRO analysis (USGS survey, sea level, VTAOT plans)

USGS survey

Datum tie between USGS survey and VTAOT plans

To obtain VTAOT datum and

mean sea level, add 299.5 feet to USGS survey.

Description of reference marks used to determine USGS datum. $\quad$ RM1 is a chiseled X on

top of the downstream end of the right abutment (elev. $504.03 \mathrm{ft}$, arbitrary survey datum). RM2

is a brass tablet on top of the upstream end of the left abutment (elev. $500.65 \mathrm{ft}$, arbitrary survey

datum).

\section{Cross-Sections Used in WSPRO Analysis}

\begin{tabular}{cccl}
\hline${ }^{1}$ Cross-section & $\begin{array}{c}\text { Section } \\
\text { Reference } \\
\text { Distance } \\
\text { (SRD) in feet }\end{array}$ & $\begin{array}{c}{ }^{2} \text { Cross-section } \\
\text { development }\end{array}$ & \multicolumn{1}{c}{ Comments } \\
\hline EXITX & -90 & 1 & $\begin{array}{l}\text { Exit section } \\
\text { Downstream Full-valley } \\
\text { section (Templated from } \\
\text { EXITL) }\end{array}$ \\
BRIDG & 0 & 2 & $\begin{array}{l}\text { Bridge section } \\
\text { RDWAY }\end{array}$ \\
APPRO & 14 & 1 & $\begin{array}{l}\text { Road Grade section } \\
\text { Modelled Approach sec- } \\
\text { tion (Templated from } \\
\text { APTEM) }\end{array}$ \\
APTEM & 185 & 2 & $\begin{array}{l}\text { Approach section as sur- } \\
\text { veyed (Used as a tem- } \\
\text { plate) }\end{array}$ \\
\hline
\end{tabular}

${ }^{1}$ For location of cross-sections see plan-view sketch included with Level I field form, Appendix E.

For more detail on how cross-sections were developed see WSPRO input file. 


\section{Data and Assumptions Used in WSPRO Model}

Hydraulic analyses of the reach were done by use of the Federal Highway Administration's WSPRO step-backwater computer program (Shearman and others, 1986, and Shearman, 1990). The analyses reported herein reflect conditions existing at the site at the time of the study. Furthermore, in the development of the model it was necessary to assume no accumulation of debris or ice at the site. Results of the hydraulic model are presented in the Bridge Hydraulic Summary, Appendix B, and figure 7.

Channel roughness factors (Manning's " $n$ ") used in the hydraulic model were estimated using field inspections at each cross section following the general guidelines described by Arcement and Schneider (1989). Final adjustments to the values were made during the modelling of the reach. Channel " $n$ " values for the reach ranged from 0.045 to 0.050 , and overbank " $n$ " values were 0.030 .

Normal depth at the exit section (EXITX) was assumed as the starting water surface. This depth was computed by use of the slope-conveyance method outlined in the user's manual for WSPRO (Shearman, 1990). The slope used was $0.013 \mathrm{ft} / \mathrm{ft}$ which was estimated from the 100-year discharge water surface slope downstream of the bridge in the Flood Insurance Study for Chester, VT (Federal Emergency Management Agency, February 1982). This $0.013 \mathrm{ft} / \mathrm{ft}$ slope was equivalent to the slope estimated from the topographic map (U.S. Geological Survey, 1971).

The surveyed approach section (APTEM) was moved along the approach channel slope $(0.0012 \mathrm{ft} / \mathrm{ft})$ to establish the modelled approach section (APPRO), one bridge length upstream

of the upstream face as recommended by Shearman and others (1986). This approach also provides a consistent method for determining scour variables. 


\section{Bridge Hydraulics Summary}

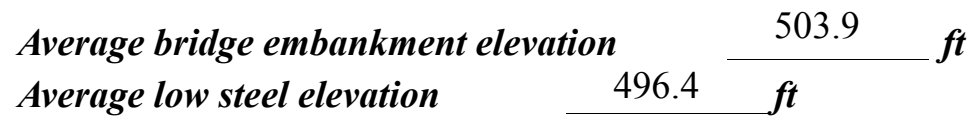

$$
\text { 100-year discharge } \quad 5,810 \quad \mathrm{ft}^{3} / \mathrm{s}
$$

Water-surface elevation in bridge opening $\quad 494.2 \quad f t$

Road overtopping? ___ N Discharge over road ___ -- $\mathrm{ft}^{3} / \mathrm{s}$

Area of flow in bridge opening $\quad 567 \quad \mathrm{ft}^{2}$

Average velocity in bridge opening $10.3 \mathrm{ft} / \mathrm{s}$

$\begin{array}{lll}\text { Maximum WSPRO tube velocity at bridge } & 12.2 \mathrm{ft} / \mathrm{s}\end{array}$

Water-surface elevation at Approach section with bridge 494.8

Water-surface elevation at Approach section without bridge $\quad \overline{495.6}$

Amount of backwater caused by bridge N/A it

500-year discharge $\quad 8,510 \quad \mathrm{ft}^{3} / \mathrm{s}$

Water-surface elevation in bridge opening $\quad 496.0 \mathrm{ft}$

Road overtopping? ___ N Discharge over road ___ -- $f^{3} / \mathrm{s}$

Area of flow in bridge opening $\quad 695 \quad \mathrm{ft}^{2}$

Average velocity in bridge opening $12.2 \mathrm{ft} / \mathrm{s}$

Maximum WSPRO tube velocity at bridge 15.3 , s

Water-surface elevation at Approach section with bridge 496.9

Water-surface elevation at Approach section without bridge $\quad 497.6$

Amount of backwater caused by bridge N/A , t

Incipient overtopping discharge ___ -- $\mathrm{ft}^{3} / \mathrm{s}$

Water-surface elevation in bridge opening $\quad--\quad t$

Area of flow in bridge opening _ -- $\mathrm{ft}^{2}$

Average velocity in bridge opening __-- $\mathrm{ft} / \mathrm{s}$

Maximum WSPRO tube velocity at bridge _-- $\mathrm{ft} / \mathrm{s}$

Water-surface elevation at Approach section with bridge

Water-surface elevation at Approach section without bridge

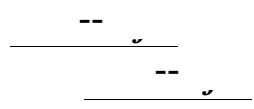

Amount of backwater caused by bridge _ 


\section{Scour Analysis Summary}

\section{Special Conditions or Assumptions Made in Scour Analysis}

Scour depths were computed using the general guidelines described in Hydraulic Engineering Circular 18 (Richardson and others, 1995). Scour depths were calculated assuming an infinite depth of erosive material and a homogeneous particle-size distribution. The results of the scour analysis are presented in tables 1 and 2 and a graph of the scour depths is presented in figure 8 .

Contraction scour for all modelled discharges was computed by use of the Laursen's live-bed contraction scour equation (Richardson and others, 1995, p. 30, equations 17 and 18). At this site, the 100-year and 500-year discharges resulted in free surface flow. Results of this analysis are presented in figure 8 and tables 1 and 2 . The streambed armoring depths computed suggest that armoring will not limit the depth of contraction scour.

Abutment scour was computed by use of the Froehlich equation (Richardson and others, 1995, p. 48, equation 28). Variables for the Froehlich equation include the Froude number of the flow approaching the embankments, the length of the embankment blocking flow, and the depth of flow approaching the embankment less any roadway overtopping.

Because the influence of scour processes on the spill-through embankment material is uncertain, the scour depth at the vertical concrete abutment walls is unknown. Therefore, the total scour depths were applied for the entire spill-through embankment below the elevation at the toe of each embankment as shown in figure 8. 


\section{Scour Results}

100-yr discharge 500-yr discharge

Incipient

Contraction scour:

(Scour depths in feet)

Main channel

Live-bed scour

Clear-water scour

Depth to armoring

Left overbank

Right overbank

Local scour:

Abutment scour

7.9

10.3

-- 7.0

Left abutment

8.9-

Right abutment

Pier scour

Pier 1

Pier 2

$$
0.0
$$

$5.1^{-}$
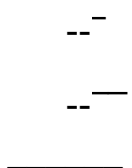

overtopping discharge

Pier 3

Abutments:

Left abutment

Right abutment

Piers:

Pier 1

Pier 2

\section{Riprap Sizing}

Incipient overtopping 100-yr discharge 500-yrdischarge discharge

3.5

$$
\text { ( } D_{50} \text { in feet) }
$$

3.5

$-{ }^{-}$

$--$

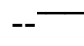

--

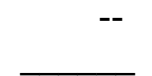

$--^{-}$
$--$

---

--

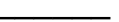




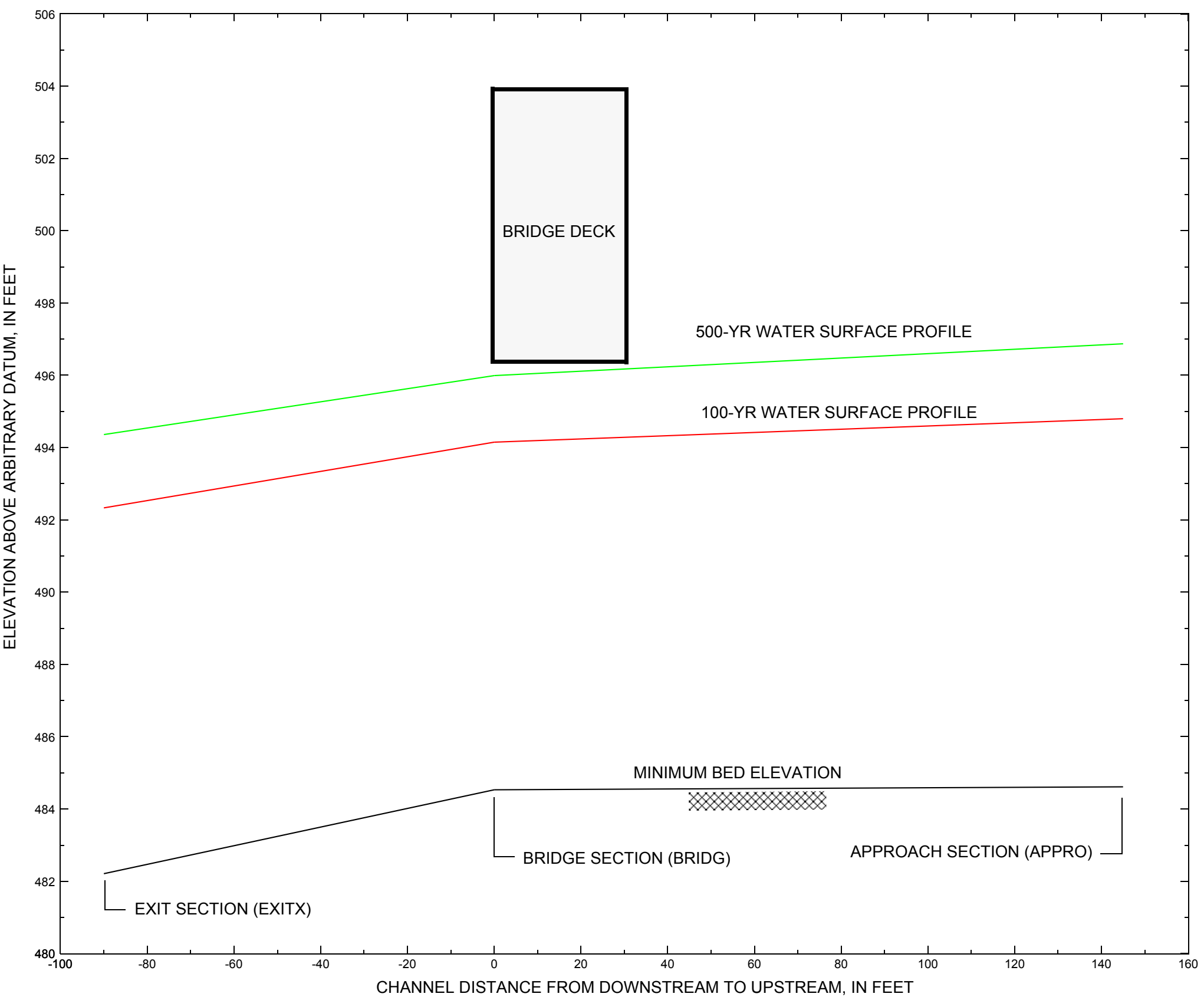

Figure 7. Water-surface profiles for the 100- and 500-yr discharges at structure CHESVT00110046 on Vermont 11, crossing the Middle Branch Williams River, Chester, Vermont. 


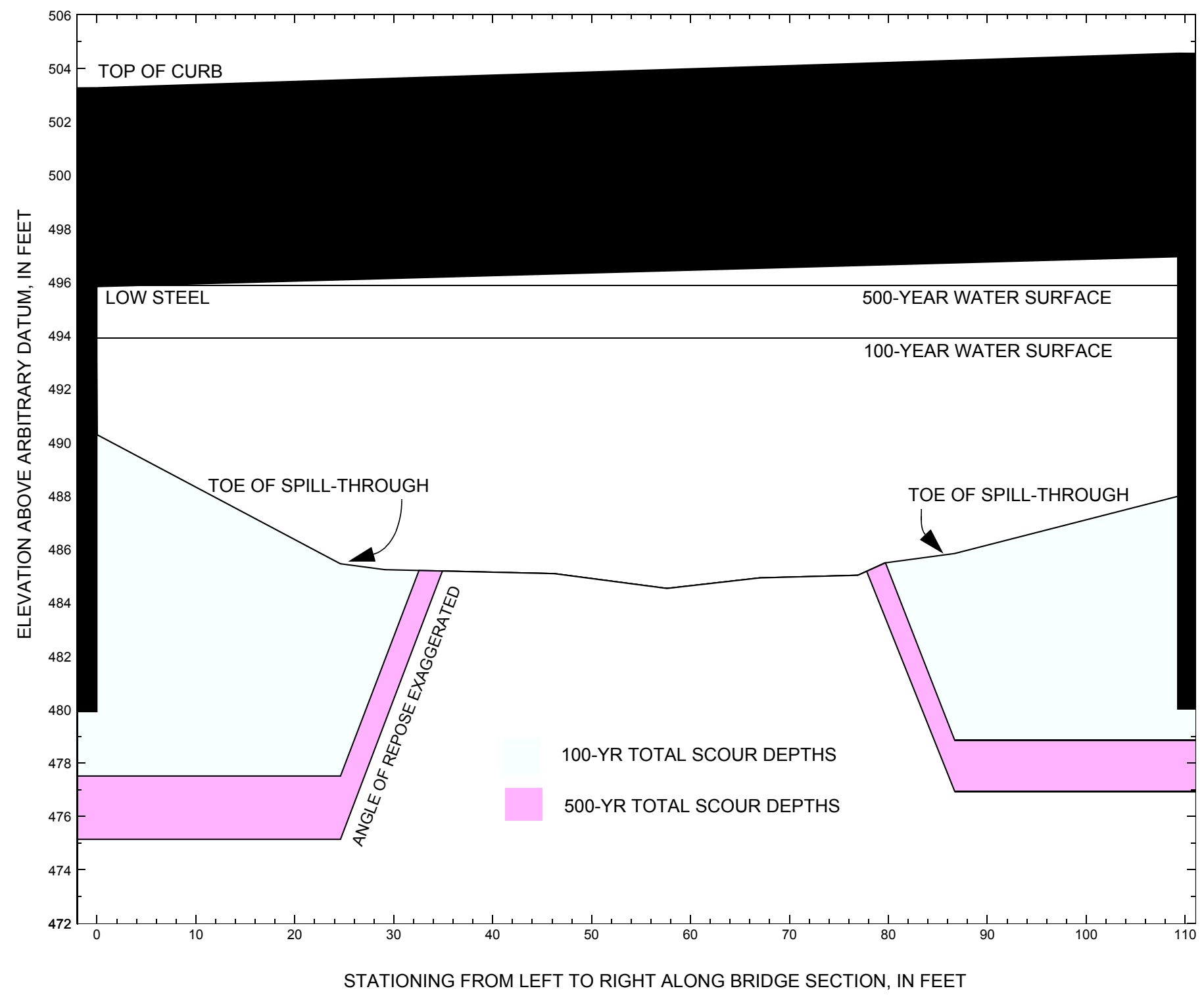

Figure 8. Scour elevations for the 100-yr and 500-yr discharges at structure CHESVT00110046 on Vermont 11, crossing the Middle Branch Williams River, Chester, Vermont. 
Table 1. Remaining footing/pile depth at abutments for the 100-year discharge at structure CHESVT00110046 on State Route 11, crossing the Middle Branch Williams River, Chester, Vermont.

[VTAOT, Vermont Agency of Transportation; --,no data]

\begin{tabular}{|c|c|c|c|c|c|c|c|c|c|c|c|}
\hline Description & Station $^{1}$ & $\begin{array}{l}\text { VTAOT } \\
\text { minimum } \\
\text { low-chord } \\
\text { elevation } \\
\text { (feet) }\end{array}$ & $\begin{array}{c}\text { Surveyed } \\
\text { minimum } \\
\text { low-chord } \\
\text { elevation } \\
\text { (feet) }\end{array}$ & $\begin{array}{c}\text { Bottom of } \\
\text { footing } \\
\text { elevation } \\
\text { (feet) }\end{array}$ & $\begin{array}{c}\text { Channel } \\
\text { elevation at } \\
\text { abutment/ } \\
\text { pier }^{2} \\
\text { (feet) }\end{array}$ & $\begin{array}{l}\text { Contraction } \\
\text { scour depth } \\
\text { (feet) }\end{array}$ & $\begin{array}{l}\text { Abutment } \\
\text { scour } \\
\text { depth } \\
\text { (feet) }\end{array}$ & $\begin{array}{l}\text { Pier } \\
\text { scour } \\
\text { depth } \\
\text { (feet) }\end{array}$ & $\begin{array}{l}\text { Depth of } \\
\text { total scour } \\
\text { (feet) }\end{array}$ & $\begin{array}{c}\text { Elevation of } \\
\text { scour }^{2} \\
\text { (feet) }\end{array}$ & $\begin{array}{c}\text { Remaining } \\
\text { footing/pile } \\
\text { depth } \\
\text { (feet) }\end{array}$ \\
\hline \multicolumn{12}{|c|}{100 -yr. discharge is 5,810 cubic-feet per second } \\
\hline Left abutment & 0.0 & -- & 495.8 & 480 & 490.3 & -- & -- & -- & -- & -- & -2 \\
\hline $\begin{array}{l}\text { Spill-through } \\
\text { toe }\end{array}$ & 24.6 & -- & -- & -- & 485.5 & 0.0 & 7.9 & -- & 7.9 & 477.6 & -- \\
\hline $\begin{array}{l}\text { Spill-through } \\
\text { toe }\end{array}$ & 86.7 & -- & -- & -- & 485.8 & 0.0 & 7.0 & -- & 7.0 & 478.8 & -- \\
\hline Right abutment & 109.3 & -- & 496.9 & 480 & 488.0 & -- & -- & -- & -- & -- & -1 \\
\hline
\end{tabular}

1.Measured along the face of the most constricting side of the bridge.

2.Arbitrary datum for this study.

Table 2. Remaining footing/pile depth at abutments for the 500-year discharge at structure CHESVT00110046 on State Route 11, crossing the Middle Branch Williams River, Chester, Vermont.

[VTAOT, Vermont Agency of Transportation; --, no data]

\begin{tabular}{|c|c|c|c|c|c|c|c|c|c|c|c|}
\hline Description & Station $^{1}$ & $\begin{array}{l}\text { VTAOT } \\
\text { minimum } \\
\text { low-chord } \\
\text { elevation } \\
\text { (feet) }\end{array}$ & $\begin{array}{l}\text { Surveyed } \\
\text { minimum } \\
\text { low-chord } \\
\text { elevation } \\
\text { (feet) }\end{array}$ & $\begin{array}{l}\text { Bottom of } \\
\text { footing } \\
\text { elevation } \\
\text { (feet) }\end{array}$ & $\begin{array}{c}\text { Channel } \\
\text { elevation at } \\
\text { abutment/ } \\
\text { pier }^{2} \\
\text { (feet) }\end{array}$ & $\begin{array}{l}\text { Contraction } \\
\text { scour depth } \\
\text { (feet) }\end{array}$ & $\begin{array}{l}\text { Abutment } \\
\text { scour } \\
\text { depth } \\
\text { (feet) }\end{array}$ & $\begin{array}{l}\text { Pier } \\
\text { scour } \\
\text { depth } \\
\text { (feet) }\end{array}$ & $\begin{array}{l}\text { Depth of } \\
\text { total scour } \\
\text { (feet) }\end{array}$ & $\begin{array}{c}\text { Elevation of } \\
\text { scour }^{2} \\
\text { (feet) }\end{array}$ & $\begin{array}{c}\text { Remaining } \\
\text { footing/pile } \\
\text { depth } \\
\text { (feet) }\end{array}$ \\
\hline \multicolumn{12}{|c|}{500 -yr. discharge is 8,510 cubic-feet per second } \\
\hline Left abutment & 0.0 & -- & 495.8 & 480 & 490.3 & -- & -- & -- & -- & -- & -5 \\
\hline $\begin{array}{l}\text { Spill-through } \\
\text { toe }\end{array}$ & 24.6 & -- & -- & -- & 485.5 & 0.0 & 10.3 & -- & 10.3 & 475.2 & -- \\
\hline $\begin{array}{l}\text { Spill-through } \\
\text { toe }\end{array}$ & 86.7 & -- & -- & -- & 485.8 & 0.0 & 8.9 & -- & 8.9 & 476.9 & -- \\
\hline Right abutment & 109.3 & -- & 496.9 & 480 & 488.0 & -- & -- & -- & -- & -- & -3 \\
\hline
\end{tabular}

1.Measured along the face of the most constricting side of the bridge.

2.Arbitrary datum for this study. 


\section{SELECTED REFERENCES}

Arcement, G.J., Jr., and Schneider, V.R., 1989, Guide for selecting Manning's roughness coefficients for natural channels and flood plains:

U.S. Geological Survey Water-Supply Paper 2339, 38 p.

Barnes, H.H., Jr., 1967, Roughness characteristics of natural channels: U.S. Geological Survey Water-Supply Paper 1849,213 p.

Benson, M. A., 1962, Factors Influencing the Occurrence of Floods in a Humid Region of Diverse Terrain: U.S. Geological Survey WaterSupply Paper 1580-B, 64 p.

Brown, S.A. and Clyde, E.S., 1989, Design of riprap revetment: Federal Highway Administration Hydraulic Engineering Circular No. 11, Publication FHWA-IP-89-016, 156 p.

Federal Highway Administration, 1983, Runoff estimates for small watersheds and development of sound design: Federal Highway Administration Report FHWA-RD-77-158.

Federal Highway Administration, 1993, Stream Stability and Scour at Highway Bridges: Participant Workbook: Federal Highway Administration Report FHWA-HI-91-011.

Federal Emergency Management Agency, 1982, Flood Insurance Study, Town of Chester, Windsor County, Vermont: Washington, D.C., February 1982.

Froehlich, D.C., 1989, Local scour at bridge abutments in Ports, M.A., ed., Hydraulic Engineering--Proceedings of the 1989 National Conference on Hydraulic Engineering: New York, American Society of Civil Engineers, p. 13-18.

Hayes, D.C.,1993, Site selection and collection of bridge-scour data in Delaware, Maryland, and Virginia: U.S. Geological Survey WaterResources Investigation Report 93-4017, 23 p.

Interagency Advisory Committee on Water Data, 1982, Guidelines for determining flood flow frequency: U.S. Geological Survey, Bulletin 17B of the Hydrology Subcommittee, 190 p.

Johnson, C.G. and Tasker, G.D.,1974, Progress report on flood magnitude and frequency of Vermont streams: U.S. Geological Survey OpenFile Report 74-130, 37 p.

Lagasse, P.F., Schall, J.D., Johnson, F., Richardson, E.V., Chang, F., 1995, Stream Stability at Highway Structures: Federal Highway Administration Hydraulic Engineering Circular No. 20, Publication FHWA-IP-90-014, 144 p.

Laursen, E.M., 1960, Scour at bridge crossings: Journal of the Hydraulics Division, American Society of Civil Engineers, v. 86, no. HY2, p. 39-53.

Potter, W. D., 1957a, Peak rates of runoff in the Adirondack, White Mountains, and Maine woods area, Bureau of Public Roads

Potter, W. D., 1957b, Peak rates of runoff in the New England Hill and Lowland area, Bureau of Public Roads

Richardson, E.V. and Davis, S.R., 1995, Evaluating scour at bridges: Federal Highway Administration Hydraulic Engineering Circular No. 18, Publication FHWA-IP-90-017, 204 p.

Richardson, E.V., Simons, D.B., and Julien, P.Y., 1990, Highways in the river environment: Federal Highway Administration Publication FHWA-HI-90-016.

Ritter, D.F., 1984, Process Geomorphology: W.C. Brown Co., Debuque, Iowa, 603 p.

Shearman, J.O., 1990, User's manual for WSPRO--a computer model for water surface profile computations: Federal Highway Administration Publication FHWA-IP-89-027, 187 p.

Shearman, J.O., Kirby, W.H., Schneider, V.R., and Flippo, H.N., 1986, Bridge waterways analysis model; research report: Federal Highway Administration Publication FHWA-RD-86-108, 112 p.

Talbot, A.N., 1887, The determination of water-way for bridges and culverts.

U.S. Department of Transportation, 1993, Stream stability and scour at highway bridges, Participant Workbook: Federal Highway Administration Publication FHWA HI-91-011.

U.S. Geological Survey, 1971, Andover, Vermont 7.5 Minute Series quadrangle map: U.S. Geological Survey Topographic Maps, Scale $1: 24,000$. 


\section{APPENDIX A: \\ WSPRO INPUT FILE}




\section{WSPRO INPUT FILE}

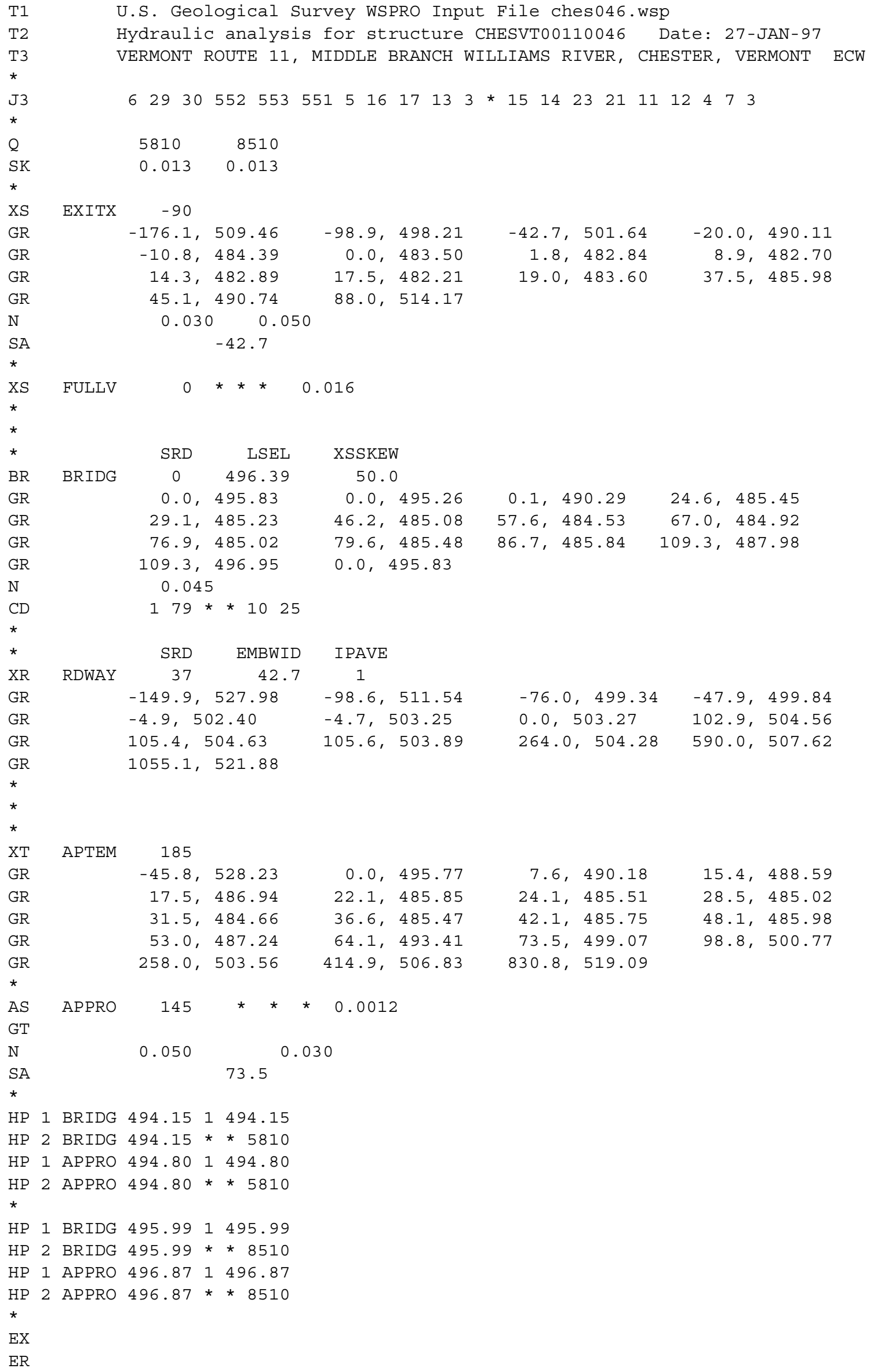




\section{APPENDIX B: \\ WSPRO OUTPUT FILE}


WSPRO OUTPUT FILE

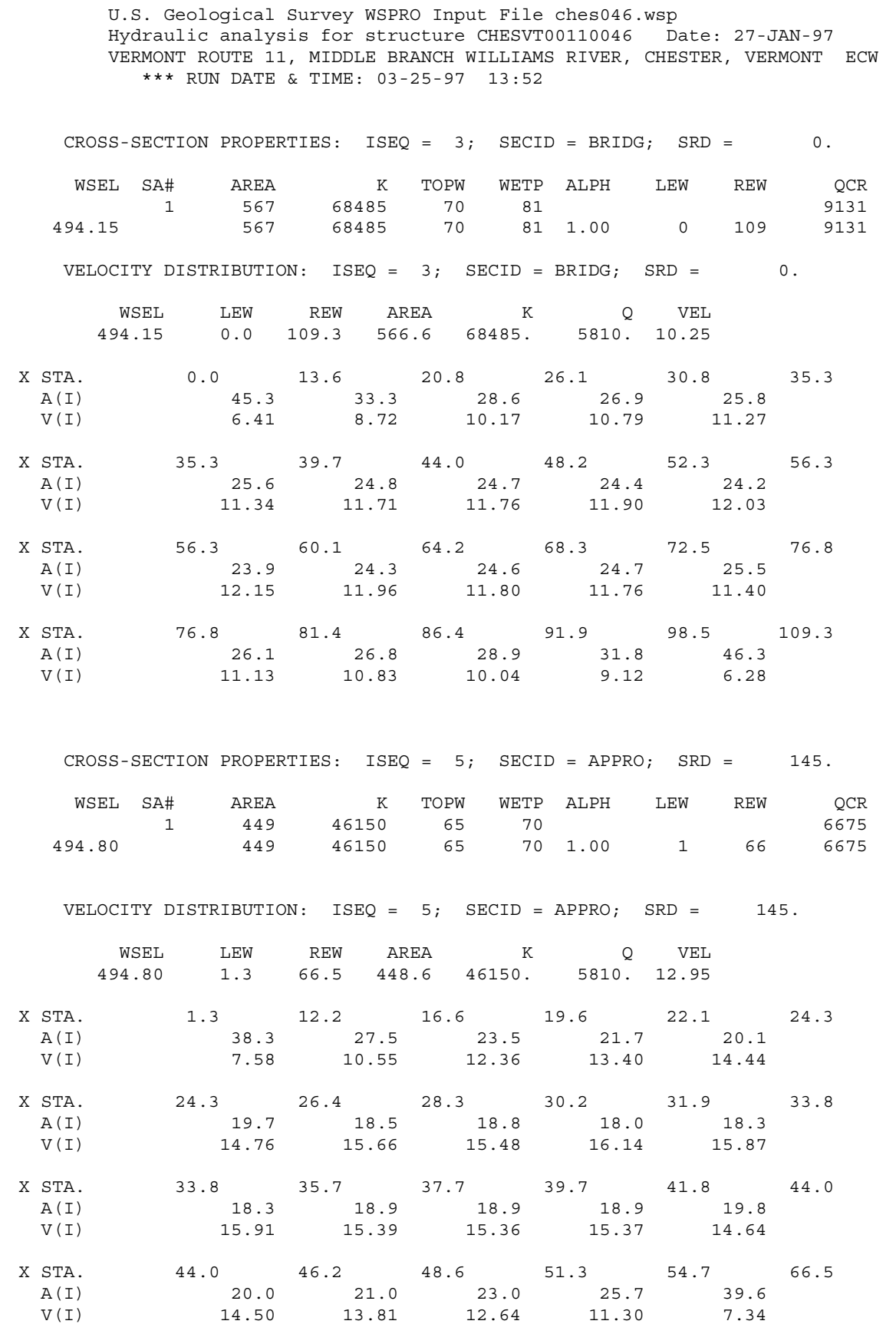


WSPRO OUTPUT FILE (continued)

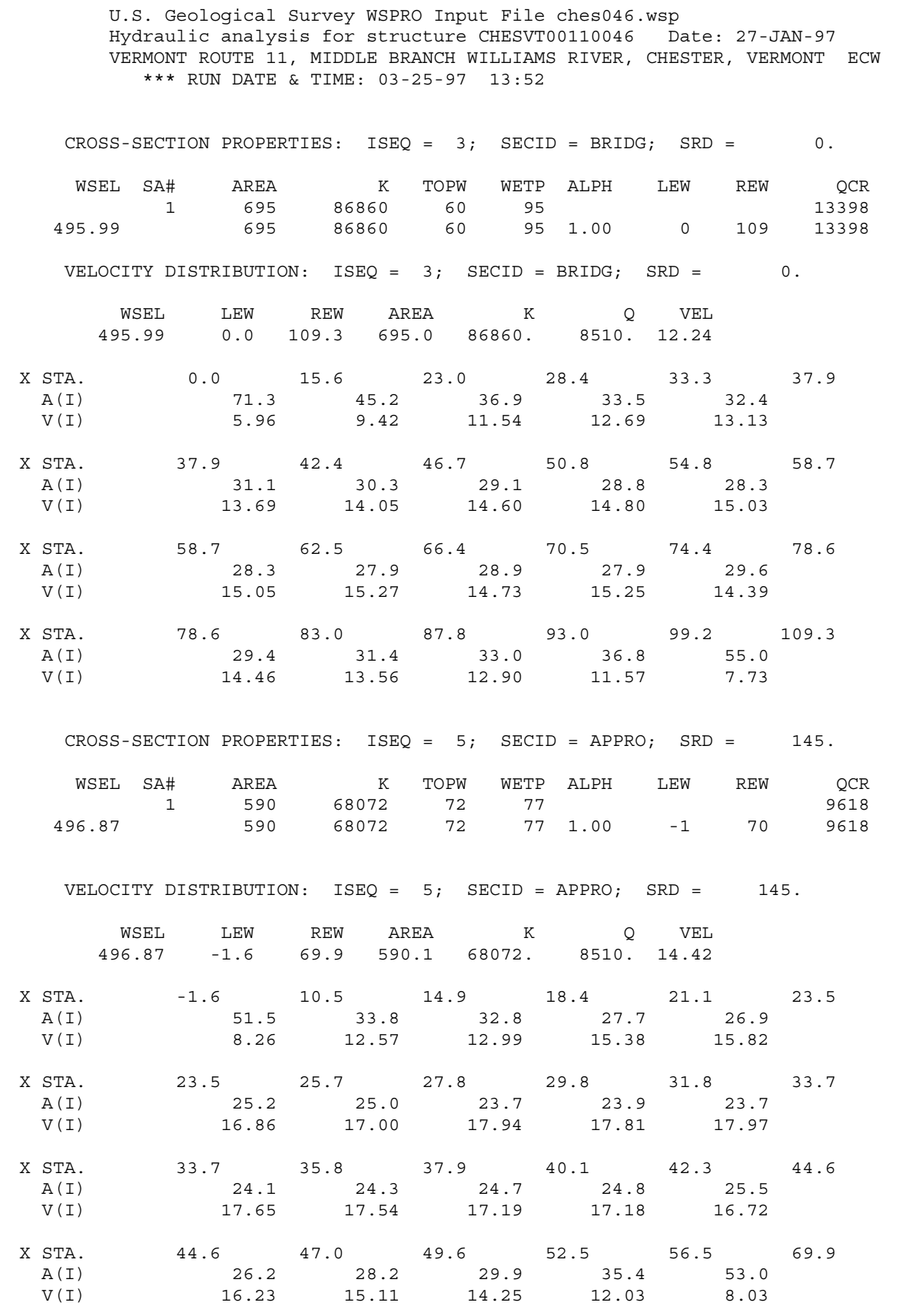


WSPRO OUTPUT FILE (continued)

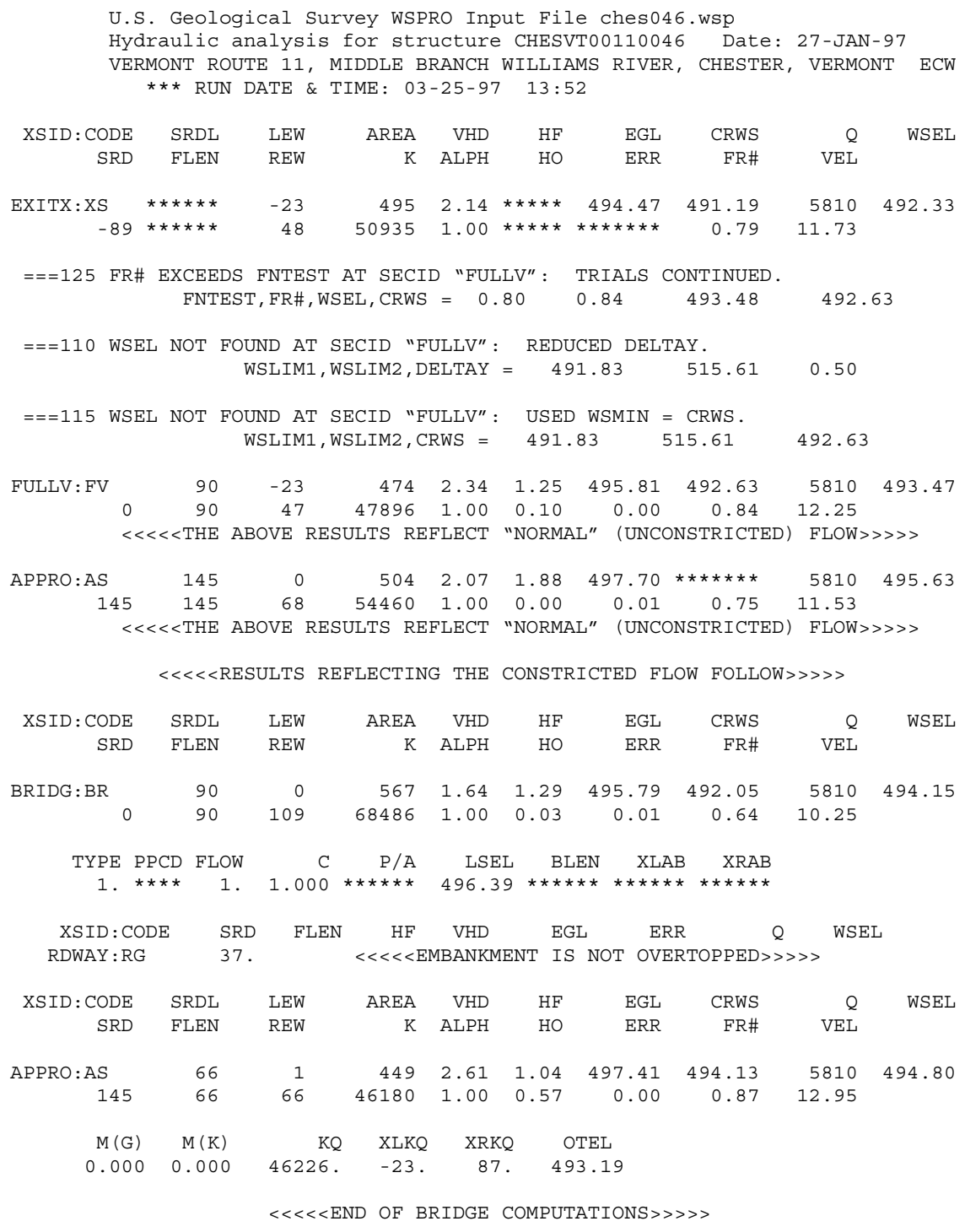

FIRST USER DEFINED TABLE.

\begin{tabular}{|c|c|c|c|c|c|c|c|c|}
\hline XSID:CODE & SRD & LEW & REW & Q & K & AREA & VEL & WSEL \\
\hline EXITX:XS & -90 & -24 & 48. & 5810. & 50935. & 495 . & 11.73 & 492.33 \\
\hline FULLV : FV & 0 . & -24 & 47. & 5810. & 47896 . & 474 . & 12.25 & 493.47 \\
\hline BRIDG : BR & 0 . & 0 . & 109. & 5810. & 68486. & 567. & 10.25 & 494.15 \\
\hline RDWAY : RG & \multicolumn{3}{|c|}{ 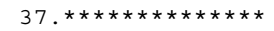 } & \multicolumn{3}{|c|}{ 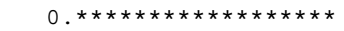 } & \multicolumn{2}{|c|}{$1.00 * * * * * * * *$} \\
\hline APPRO: AS & 145. & 1. & 66. & 5810. & 46180. & 449 . & 12.95 & 494.80 \\
\hline XSID : CODE & XLKQ & $\mathrm{XRKQ}$ & & $\mathrm{KQ}$ & & & & \\
\hline APPRO : AS & -23 . & 87. & 46 & & & & & \\
\hline
\end{tabular}

SECOND USER DEFINED TABLE.

\begin{tabular}{|c|c|c|c|c|c|c|c|c|c|}
\hline XSID : CODE & CRWS & FR\# & YMIN & YMAX & $\mathrm{HF}$ & $\mathrm{HO}$ & VHD & EGL & WSE \\
\hline EXITX:XS & 491.19 & 0.79 & 482.21 & 514.17 * & $* \star \star \star * * * *$ & 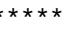 & 2.14 & 494.47 & 492.3 \\
\hline FULLV : FV & 492.63 & 0.84 & 483.65 & 515.61 & 1.25 & 0.10 & 2.34 & 495.81 & 493. \\
\hline BRIDG : BR & 492.05 & 0.64 & 484.53 & 496.95 & 1.29 & 0.03 & 1.64 & 495.79 & 494. \\
\hline RDWAY : RG & 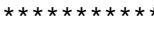 & $\star \star \star \star \star *$ & 499.34 & $527.98 *$ & 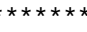 & $\star \star \star \star \star \star *$ & $\star \star \star \star \star \star * *$ & 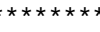 & $\star \star \star \star$ \\
\hline APPRO: AS & 494.13 & 0.87 & 484.61 & 528.18 & 1.04 & 0.57 & 2.61 & 497.41 & 494. \\
\hline
\end{tabular}


WSPRO OUTPUT FILE (continued)

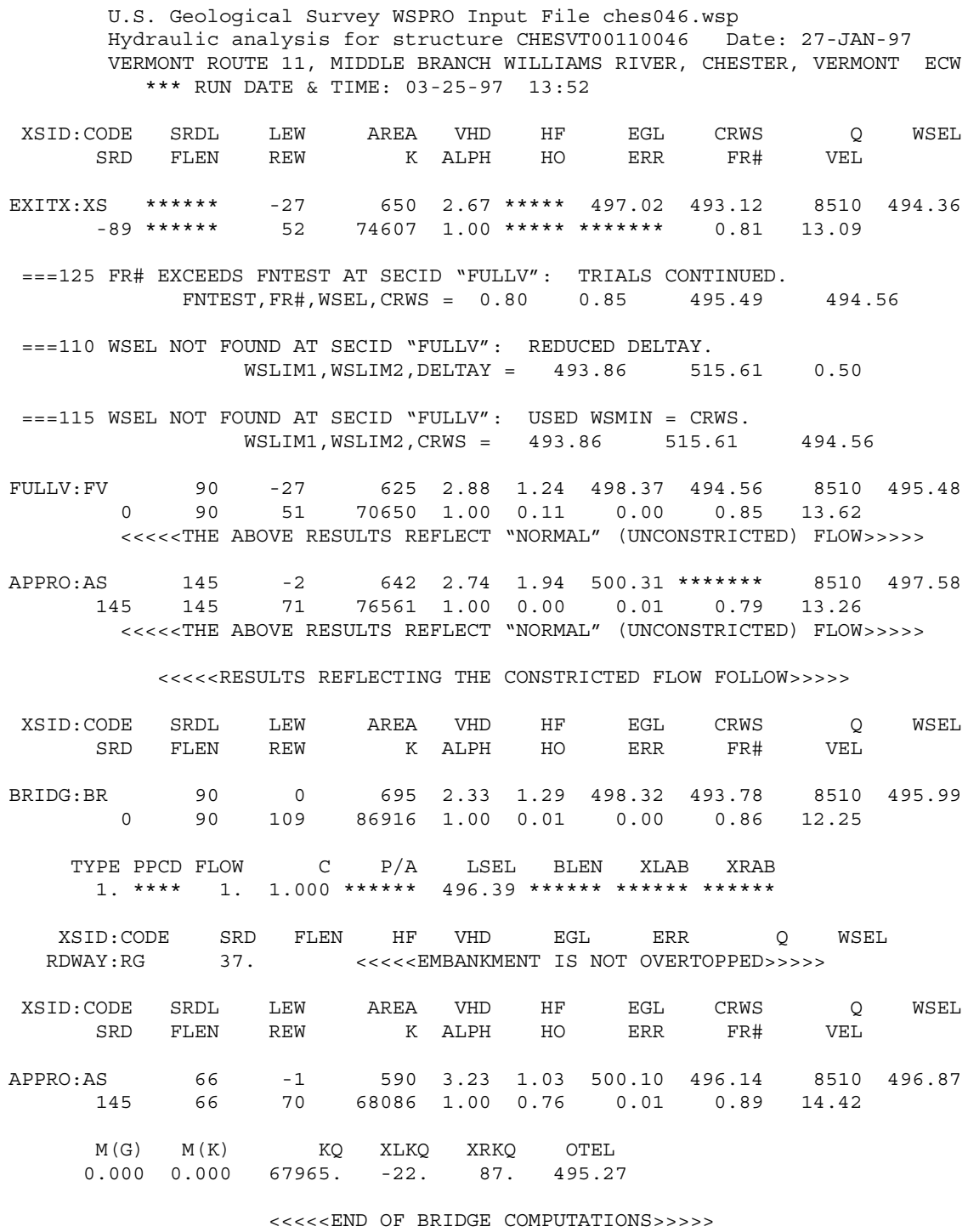

\begin{tabular}{|c|c|c|c|c|c|c|c|c|}
\hline XSID : CODE & SRD & LEW & REW & $\mathrm{Q}$ & $\mathrm{K}$ & AREA & VEL & WSEL \\
\hline EXITX:XS & -90 & -28 & 52. & 8510. & 74607 & 650. & 13.09 & 494.36 \\
\hline FULLV : FV & 0 . & -28 & 51 & 8510. & 70650 & 625. & 13.62 & 495.48 \\
\hline BRIDG : BR & 0. & 0 . & 109. & 8510. & 86916. & 695. & 12.25 & 495.99 \\
\hline RDWAY : RG & \multicolumn{3}{|c|}{$37 . * * \star \star \star * \star * \star * \star * \star * * *$} & \multicolumn{3}{|c|}{ 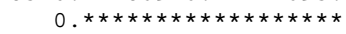 } & \multicolumn{2}{|c|}{$1.00 * * * * * * * *$} \\
\hline APPRO : AS & 145 . & -2 . & 70 . & 8510. & 68086 & 590 & 14.42 & 496.87 \\
\hline XSID : CODE & XLKQ & XRKQ & K & & & & & \\
\hline APPRO : AS & -22 & 87. & 67965 & & & & & \\
\hline
\end{tabular}

SECOND USER DEFINED TABLE.

$\begin{array}{lcrrrrrrrr}\text { XSID :CODE } & \text { CRWS } & \text { FR\# } & \text { YMIN } & \text { YMAX } & \text { HF } & \text { HO } & \text { VHD } & \text { EGL } & \text { WSEL } \\ \text { EXITX:XS } & 493.12 & 0.81 & 482.21 & 514.17 * * * * * * * * * * & 2.67 & 497.02 & 494.36 \\ \text { FULLV :FV } & 494.56 & 0.85 & 483.65 & 515.61 & 1.24 & 0.11 & 2.88 & 498.37 & 495.48 \\ \text { BRIDG :BR } & 493.78 & 0.86 & 484.53 & 496.95 & 1.29 & 0.01 & 2.33 & 498.32 & 495.99 \\ \text { RDWAY :RG } & * * * * * * * * * * * * * * & 499.34 & 527.98 * * * * * * * * * * * * * * * * * * * * * * * * * * * \\ \text { APPRO:AS } & 496.14 & 0.89 & 484.61 & 528.18 & 1.03 & 0.76 & 3.23 & 500.10 & 496.87\end{array}$




\section{APPENDIX C:}

\section{BED-MATERIAL PARTICLE-SIZE DISTRIBUTION}




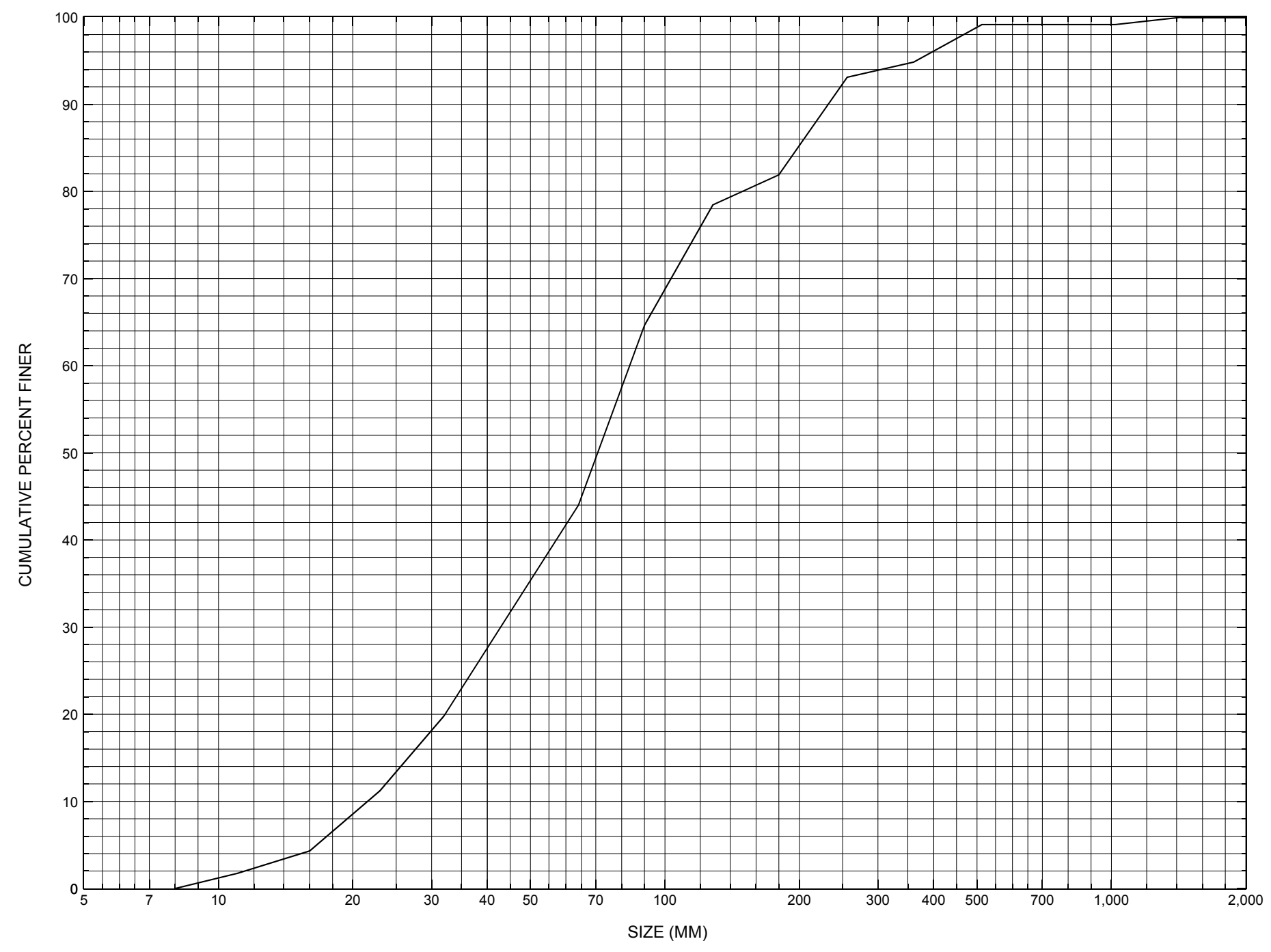

Appendix C. Bed material particle-size distribution for a pebble count in the channel approach of structure CHESVT00110046, in Chester, Vermont. 


\section{APPENDIX D: \\ HISTORICAL DATA FORM}




\section{Structure Number CHESVT00110046}

\section{General Location Descriptive}

Data collected by (First Initial, Full last name) $\mathbf{E}$. BOEHMLER

Date $(M M / D D / Y Y) \_\mathbf{0 3} / \underline{29} / \underline{95}$

Highway District Number $(I-2 ; n n) \underline{\mathbf{0 2}}$

Town (FIPS place code; I - 4; nnnnn) 13675

Waterway (I - 6) MIDDLE BR WILLIAMS RIVER

Route Number VT011

Topographic Map Andover

Latitude (I - 16; nnnn.n) $\mathbf{4 3 1 5 8}$
County (FIPS county code; I - 3; nnn)

Mile marker (I - 11; nnn.nnn) $\mathbf{0 0 2 0 9 0}$

Road Name (I - 7): -

Vicinity (I - 9) 3.0 MI W JCT. VT.103 N

Hydrologic Unit Code: $\mathbf{0 1 0 8 0 1 0 7}$

Longitude (i - 17; nnnnn.n) $\mathbf{7 2 3 8 9}$

\section{Select Federal Inventory Codes}

FHWA Structure Number $(I-8) \quad \mathbf{2 0 0 0 1 6 0 0 4 6 1 4 0 7}$

Maintenance responsibility $(I-21 ; n n) \_$01_ Maximum span length $(I-48$; nnnn) $\underline{\mathbf{0 1 1 4}}$

Year built (I - 27; YYYY) 1992

Structure length (I - 49; nnnnnn) $\underline{000118}$

Average daily traffic, ADT (I - 29; nnnnnn) 003540 Deck Width (I - 52; nn.n) 427

Year of ADT (I - 30; YY) $\mathbf{9 2}$

Channel \& Protection $(I-61 ; n) \mathbf{8}$

Opening skew to Roadway $(I-34 ; n n) \quad \mathbf{5 0}$

Waterway adequacy $(I-71 ; n)$

Operational status $(I-41 ; X)$ A

Underwater Inspection Frequency $(I-92 B ; X Y Y) \_\mathbf{N}$

Structure type (I- 43; nnn) $\mathbf{3 0 2}$

Year Reconstructed (I - 106) $\mathbf{0 0 0 0}$

Approach span structure type $(I-44 ; n n n) \quad \mathbf{0 0 0}$

Clear span (nnn.n ft) $\quad \mathbf{0 6 9 . 0}$

Number of spans (I - 45; nnn) $\underline{\mathbf{0 0 1}}$

Vertical clearance from streambed (nnn.n ft) $\underline{\mathbf{0 1 2 . 0}}$

Number of approach spans (I- 46; nnnn) $\underline{\mathbf{0 0 0 0}}$ Waterway of full opening $\left(n n n . n \mathrm{ft}^{2}\right) \underline{\mathbf{7 0 0 . 0}}$

Comments:

The structural inspection report of 11/18/93 indicates that the structure is a steel stringer type bridge with a steel plate deck and an asphalt roadway surface. The abutment walls and wingwalls are constructed of concrete and are reported in "like-new" condition. The footings are noted as not in view at the surface. The waterway proceeds straight through the structure then makes a sharp turn just downstream. The streambed consists of stone and gravel. The embankments and abutment walls are well protected with stone fill. 


\section{Bridge Hydrologic Data}

Is there hydrologic data available? $\underline{\mathbf{Y}}$ if No, type ctrl- $n$ VTAOT Drainage area $\left(\mathrm{mi}^{2}\right)^{2}: \underline{\mathbf{2 7 . 2}}$

Terrain character: Rolling to hilly

Stream character \& type: Mountainous type stream and a tributary to Williams River.

Streambed material: Sand \& gravel - armored with rock and boulders.

Discharge Data (cfs): $\quad Q_{2.33} \mathbf{1 1 5 0}$

$\mathrm{Q}_{50} 4 \mathbf{4 7 0 0}$

$Q_{10} \frac{\mathbf{2 6 5 0}}{\mathbf{5 6 5 0}}$

$\mathrm{Q}_{25} \mathbf{3 7 0 0}$

$Q_{500}$

Record flood date (MM /DD / YY): $09 / 2 / 38$ Water surface elevation (ft): -

Estimated Discharge (cfs): __ Velocity at Q $\underline{\mathbf{5 0}}(\mathrm{ft} / \mathrm{s}): \underline{\mathbf{1 2 . 4}}$

Ice conditions (Heavy, Moderate, Light): Moderate Debris (Heavy, Moderate, Light): Moderate

The stage increases to maximum highwater elevation (Rapidly, Not rapidly): Rapidly

The stream response is (Flashy, Not flashy): Flashy

Describe any significant site conditions upstream or downstream that may influence the stream's stage: -

Watershed storage area (in percent) $\mathbf{0 . 5} \%$

The watershed storage area is: 2 (1-mainly at the headwaters; 2- uniformly distributed; 3-immediatly upstream oi the site)

Water Surface Elevation Estimates for Existing Structure:

\begin{tabular}{|l|l|c|c|l|l|}
\hline Peak discharge frequency & $Q_{2.33}$ & $Q_{10}$ & $Q_{25}$ & $Q_{50}$ & $Q_{100}$ \\
Water surface elevation (ft)) & $\mathbf{7 9 1 . 2}$ & $\mathbf{7 9 3 . 0}$ & $\mathbf{7 9 4 . 0}$ & $\mathbf{7 9 4 . 9}$ & $\mathbf{7 9 5 . 7}$ \\
Velocity $(\mathrm{ft} / \mathrm{sec})$ & $\mathbf{8 . 5}$ & $\mathbf{1 0 . 7}$ & $\mathbf{1 1 . 7}$ & $\mathbf{1 2 . 5}$ & $\mathbf{1 3 . 3}$ \\
\hline
\end{tabular}

Long term stream bed changes: Scour estimate indicated on report is $\mathbf{4}$ feet calculated.

Is the roadway overtopped below the $\mathrm{Q}_{100}$ ? (Yes, No, Unknown): $\mathbf{N} \quad$ Frequency: -

Relief Elevation $(f t)$ :

Discharge over roadway at $Q_{100}\left(f t^{3} / \mathrm{sec}\right)$ :

Are there other structures nearby? (Yes, No, Unknown): $\mathbf{Y}$ Upstream distance (miles): $\mathbf{0 . 3}$

Highway No. : VT11

Town: Chester If No or Unknown, type ctrl-n os

Clear span (ft): $\mathbf{7 0 . 0}$ Clear Height $(f t): \underline{\mathbf{1 1 . 0}}$ Full Waterway $\left(f t^{2}\right): \underline{\mathbf{7 7 0 . 0}}$ 
Downstream distance (miles): $\mathbf{0 . 7 5}$ Town:

Chester

Year Built:

Highway No. : TH57

Structure No. : 69

Structure Type:

Clear span (ft): $\underline{\mathbf{4 0 . 0}}$ Clear Height $(f t): \underline{\mathbf{1 0 . 0}}$ Full Waterway $\left(f^{2}\right): \underline{\mathbf{4 0 0 . 0}}$

Comments:

Hydraulic report recommended class III stone fill to be used for protection.

\section{USGS Watershed Data}

Watershed Hydrographic Data

Drainage area $(D A)$

Watershed storage (ST)

Bridge site elevation

Main channel length

780

9.22

$10 \%$ channel length elevation $\mathbf{8 6 0}$

Main channel slope

(S)

109.08 $\mathrm{ft} / \mathrm{mi}$ $\%$ $\mathrm{mi}$

Lake and pond area

0 $\mathrm{mi}^{2}$

Headwater elevation 2894 $\mathrm{ft}$ $\mathrm{ft} \quad 85 \%$ channel length elevation $\mathrm{ft}$

\section{Watershed Precipitation Data}

Average site precipitation in

Average headwater precipitation in

Maximum 2yr-24hr precipitation event $(124,2)$ in

Average seasonal snowfall (Sn) $\mathrm{ft}$ 


\section{Bridge Plan Data}

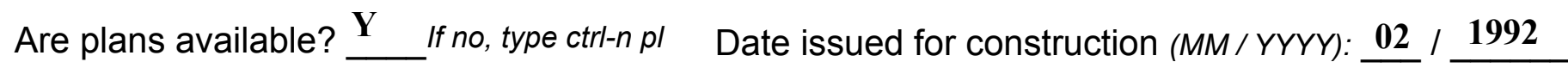
Project Number BRF-F016-1(3) Minimum channel bed elevation: $\mathbf{7 8 4 . 5}$

Low superstructure elevation: USLAB DSLAB USRAB DSRAB -

Benchmark location description:

VTAOT reference mark, bronze disk on top of concrete at corner where the upstream left wingwall and left abutment meet, no elevation is shown on plans yet for this mark as plans are not finalized.

Reference Point (MSL, Arbitrary, Other): MSL Datum (NAD27, NAD83, Other): NGVD1929 Foundation Type: 1

If 1 : Footing Thickness $\mathbf{2 . 5} \quad$ Footing bottom elevation: $\underline{\mathbf{7 7 9 . 0}}$

If 2: Pile Type:___ (1-Wood; 2-Steel or metal; 3-Concrete) Approximate pile driven length:

If 3: Footing bottom elevation:

Is boring information available? $\mathbf{N}$ If no, type ctrl- $n$ bi Number of borings taken: _-

Foundation Material Type: $\mathbf{3}$ (1-regolith, 2-bedrock, 3-unknown)

Briefly describe material at foundation bottom elevation or around piles:

Some borings may eventually be available on the plans when finalized.

Comments:

Other points shown on the plans with elevations are: 1) The point on the streamward edge on top of the concrete at the end of the upstream left wingwall, elevation 799.50; and 2) the point at the same location but on the upstream right wingwall, elevation 800.50 . 


\section{Cross-sectional Data}

Is cross-sectional data available? NO If no, type ctrl-n xs

Source (FEMA, VTAOT, Other)? -

Comments: FEMA data (February 1982) of bridge cross-section pre-dates this bridge, which was built in 1992.

\begin{tabular}{|l|l|l|l|l|l|l|l|l|l|l|l|}
\hline Station & & - & - & - & - & - & - & - & - & - & - \\
\hline Feature & - & - & - & - & - & - & - & - & - & - & - \\
\hline $\begin{array}{l}\text { Low cord } \\
\text { elevation }\end{array}$ & - & - & - & - & - & - & - & - & - & - & - \\
\hline $\begin{array}{l}\text { Bed } \\
\text { elevation }\end{array}$ & - & - & - & - & - & - & - & - & - & - & - \\
\hline $\begin{array}{l}\text { Low cord to } \\
\text { bed length }\end{array}$ & - & - & - & - & - & - & - & - & - & - & - \\
\hline Station & - & - & - & - & - & - & - & - & - & - & - \\
\hline Feature & - & - & - & - & - & - & - & - & - & - & \\
\hline $\begin{array}{l}\text { Low cord } \\
\text { elevation }\end{array}$ & - & - & - & - & - & - & - & - & - & - & - \\
\hline $\begin{array}{l}\text { Bed } \\
\text { elevation }\end{array}$ & - & - & - & - & - & - & - & - & - & - & - \\
\hline $\begin{array}{l}\text { Low cord to } \\
\text { bed length }\end{array}$ & - & - & - & - & - & - & - & - & - & - & - \\
\hline
\end{tabular}

Source (FEMA, VTAOT, Other)?

Comments: -

\begin{tabular}{|l|l|l|l|l|l|l|l|l|l|l|l|}
\hline Station & - & - & - & - & - & - & - & - & - & - & - \\
\hline Feature & - & - & - & - & - & - & - & - & - & - & - \\
\hline $\begin{array}{l}\text { Low cord } \\
\text { elevation }\end{array}$ & - & - & - & - & - & - & - & - & - & - & - \\
\hline $\begin{array}{l}\text { Bed } \\
\text { elevation }\end{array}$ & - & - & - & - & - & - & - & - & - & - & - \\
\hline $\begin{array}{l}\text { Low cord to } \\
\text { bed length }\end{array}$ & - & - & - & - & - & - & - & - & - & - & - \\
\hline Station & - & - & - & - & - & - & - & - & - & - & - \\
\hline Feature & - & - & - & - & - & - & - & - & - & - & - \\
\hline $\begin{array}{l}\text { Low cord } \\
\text { elevation }\end{array}$ & - & - & - & - & - & - & - & - & - & - & - \\
\hline $\begin{array}{l}\text { Bed } \\
\text { elevation }\end{array}$ & - & - & - & - & - & - & - & - & - & - & - \\
\hline $\begin{array}{l}\text { Low cord to } \\
\text { bed length }\end{array}$ & - & - & - & - & - & - & - & - & - & - & - \\
\hline
\end{tabular}




\section{APPENDIX E: \\ LEVEL I DATA FORM}


U. S. Geological Survey

Bridge Field Data Collection and Processing Form

Qa/Qc Check by: $\underline{\mathbf{R B}}$ Date: $10 / 02 / 96$

\section{Structure Number CHESVT00110046}

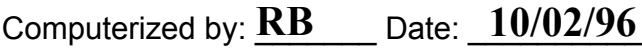

Reviewd by: $\quad$ EW Date: $\underline{4 / 7 / 97}$

\section{A. General Location Descriptive}

1. Data collected by (First Initial, Full last name) E. WILD

2. Highway District Number $\mathbf{0 2}$

Date $(M M / D D / Y Y) \underline{09} / \underline{12} / \underline{1996}$

County 027 WINDSOR

Waterway $(l$ - 6) MIDDLE BR. WILLIAMS RIVER

Route Number VT11

Mile marker 002090

Town 13675 CHESTER

Road Name -

Hydrologic Unit Code: $\mathbf{0 1 0 8 0 1 0 7}$

3. Descriptive comments:

Located 3.0 miles west of the junction with VT 103 North. This is a steel stringer type bridge with a steel plate deck and an asphalt roadway surface.

\section{B. Bridge Deck Observations}
4. Surface cover... LBUS 6
RBUS 4
LBDS 4
RBDS 6
Overall 6

(2b us,ds,lb,rb: 1- Urban; 2- Suburban; 3- Row crops; 4- Pasture; 5- Shrub- and brushland; 6- Forest; 7- Wetland)
5. Ambient water surface... US 2
UB 1
DS 2
(1- pool; 2- riffle)

6. Bridge structure type 1 (1- single span; 2- multiple span; 3- single arch; 4- multiple arch; 5-cylindrical culvert; 6- box culvert; or 7- other)
7. Bridge length 118
(feet)
Span length 114
(feet)
Bridge width $\underline{42.7}$ (feet)

\section{Road approach to bridge:}
8. LB $\mathbf{0}$ RB $\mathbf{0}$
( 0 even, 1- lower, 2- higher)
9. LB 1 RB 1
(1- Paved, 2- Not paved)

10. Embankment slope (run / rise in feet / foot)

US left

US right

\begin{tabular}{|c|c|c|c|}
\hline \multicolumn{2}{|c|}{ Protection } & \multirow{2}{*}{ 13.Erosion } & 14.Severity \\
\hline 11.Type & 12.Cond. & $\mathbf{0}$ & - \\
\hline $\mathbf{2}$ & $\mathbf{1}$ & $\mathbf{0}$ & - \\
$\mathbf{2}$ & $\mathbf{1}$ & $\mathbf{0}$ & - \\
\hline $\mathbf{0}$ & - & $\mathbf{0}$ & - \\
\hline $\mathbf{0}$ & - & $\mathbf{0}$ & - \\
\hline
\end{tabular}

Bank protection types: 0- none; 1- < 12 inches,

2- $<36$ inches; $3-<48$ inches;

4- < 60 inches; 5- wall / artificial levee

Bank protection conditions: 1- good; 2- slumped;

3- eroded; 4- failed

Erosion: 0 - none; 1- channel erosion; 2 -

road wash; 3- both; 4- other

Erosion Severity: 0 - none; 1- slight; 2- moderate; 3- severe

\section{Channel approach to bridge (BF):}

15. Angle of approach: $\mathbf{0}$

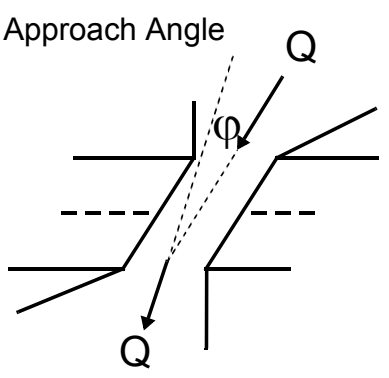

17. Channel impact zone 1 :

Where? LB $(L B, R B)$

Range? $\underline{350}$ feet $\underline{\text { US }}$

Channel impact zone 2:

Where? RB $(L B, R B)$

Range? 90 feet $\underline{\mathbf{D S}}$ (US, UB, DS) to $\underline{157}$ feet $\underline{\mathbf{D S}}$

Impact Severity: 0- none to very slight; 1- Slight; 2- Moderate; 3- Severe
16. Bridge skew: 45 Bridge Skew Angle

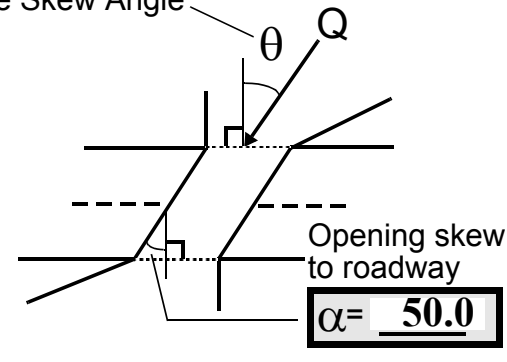

\section{Exist? $\mathbf{Y}(Y$ or $N)$}

Severity 1

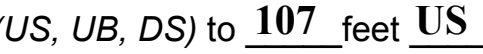

Exist? $\mathbf{Y}(\mathrm{Y}$ or $N)$

Severity 1 
18. Bridge Type: 1a

1a- Vertical abutments with wingwalls

1 b- Vertical abutments without wingwalls

2- Vertical abutments and wingwalls, sloping embankment Wingwalls perpendicular to abut. face

3- Spill through abutments

4- Sloping embankment, vertical wingwalls and abutments

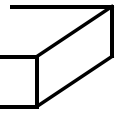

1a with wingwalls

Wingwall angle less than $90^{\circ}$.

19. Bridge Deck Comments (surface cover variations, measured bridge and span lengths, bridge type variations, approach overflow width, etc.)

4. The left bank upstream and right bank downstream are steep forested hills. The right bank upstream has a dirt parking area and grass along VT 11. The left bank downstream is grass and small trees along VT 11 and forest beyond.

5. The upstream is a series of pool and riffle. Under the bridge it is mostly pooled. Downstream the water surface is riffle until 100 feet downstream where the bedrock is in the channel and there is a scour hole and the water is pooled.

7. Values are from the Vermont AOT database. Measured bridge length is $\mathbf{1 1 3 . 7}$ feet downstream and 119.4 feet upstream, span length is 107 feet downstream and 113.4 feet upstream, and bridge width is 41.5 feet.

8. Both road approaches are even, but the bridge is banked so that the downsteam face of the bridge is higher than the upstream.

17. There is no cut bank in the impact zone downstream, though it is a very sharp bend in the stream because the right bank is all bedrock.

\section{Upstream Channel Assessment}

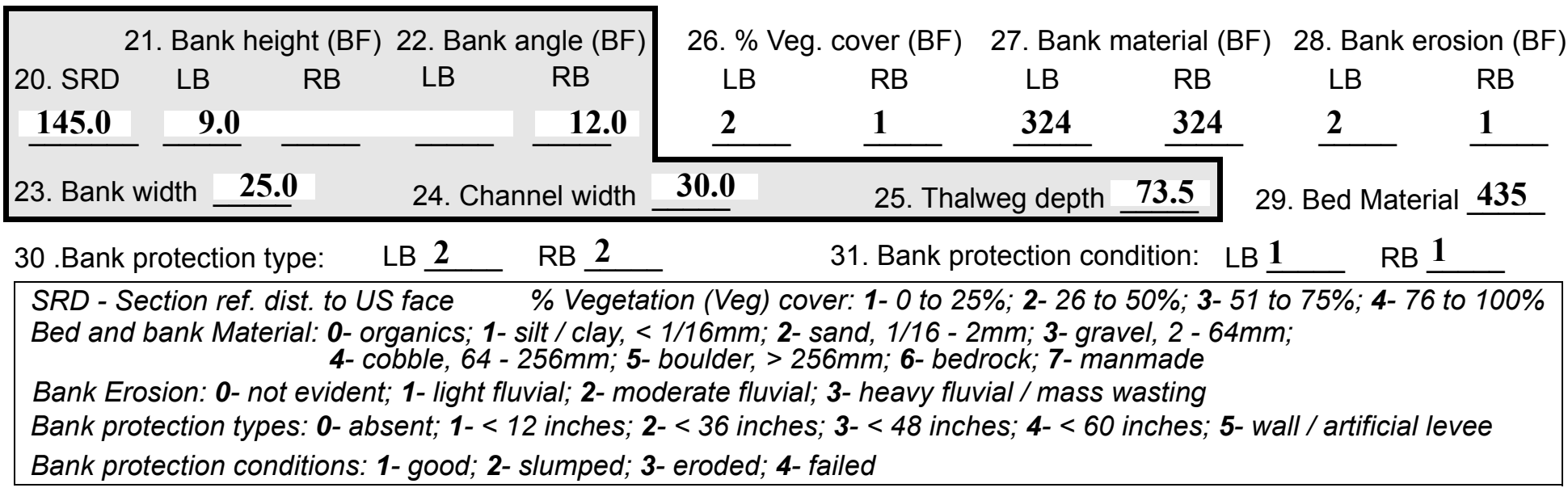

32. Comments (bank material variation, minor inflows, protection extent, etc.):

27. On the left and right banks near the bridge, the bank material is all placed bank protection.

28. The left bank is creeping into the channel as a side bar US of the protection. There is light fluvial erosion on the right bank US of the protection.

30. The left bank protection extends $129 \mathrm{ft}$. US to $0 \mathrm{ft}$. US. The right bank protection extends from the wingwall to $165 \mathrm{ft}$ upstream. 
36. Point bar extent: $\underline{\mathbf{1 8 2}}$ feet $\underline{\mathrm{US}}$ (US, UB) to $\underline{\mathbf{1 0}}$ feet $\underline{\mathrm{US}}$ (US, UB, DS) positioned $\underline{\mathbf{5 0}} \%$ LB to $100 \%$ RB

37. Material: $\underline{\mathbf{4 3 5 2}}$

38. Point or side bar comments (Circle Point or Side; Note additional bars, material variation, status, etc.):

An additional side bar extends from 278 feet upstream to 170 feet upstream. It is mostly cobble with some boulders, gravel and grass. It is $\mathbf{1 2 . 5}$ feet wide uniformly throughout. It is positioned from $0 \% \mathrm{LB}$ to $\mathbf{4 0 \%}$ RB.

39. Is a cut-bank present? $\mathbf{N}$ ( $Y$ or if $N$ type ctrl-n $c b)$ 40. Where? - $(L B$ or $R B)$

41. Mid-bank distance: -

42. Cut bank extent: feet (US, UB) to feet (US, UB, DS)

43. Bank damage: (1- eroded and/or creep; 2- slip failure; 3- block failure)

44. Cut bank comments (eg. additional cut banks, protection condition, etc.):

NO CUT BANKS

45. Is channel scour present? $\mathbf{N}$ (Y or if $N$ type ctrl-n cs)

47. Scour dimensions: Length Width Depth : 46. Mid-scour distance: -

48. Scour comments (eg. additional scour areas, local scouring process, etc.):

\section{NO CHANNEL SCOUR}

Some localized scour near large boulders in the stream.

49. Are there major confluences? $\mathbf{N}$

51. Confluence 1: Distance Confluence 2: Distance -
52. Enters on -

Enters on -
( $Y$ or if $N$ type ctrl-n $m c$ ) (LB or $R B)$ (LB or $R B)$

54. Confluence comments (eg. confluence name):

50. How many? -

53. Type(1- perennial; 2- ephemeral)

Type (1- perennial; 2- ephemeral)

\section{NO MAJOR CONFLUENCES}

\section{Under Bridge Channel Assessment}

55. Channel restraint (BF)? LB 2

56. Height (BF)
LB RB
$\mathbf{3 5 . 5}-$
58. Bank width (BF) -
(1- natural bank; 2- abutment; 3- artificial levee)

Bed and bank Material: 0- organics; 1- silt / clay, < 1/16mm; 2- sand, 1/16 - 2mm; 3- gravel, 2 - 64mm; 4- cobble, 64 - 256mm; 5- boulder, > 256mm; 6- bedrock; 7- manmade

Bank Erosion: 0- not evident; 1- light fluvial; 2- moderate fluvial; 3- heavy fluvial / mass wasting

64. Comments (bank material variation, minor inflows, protection extent, etc.):

43 
65. Debris and Ice Is there debris accumulation?

67. Debris Potential (1- Low; 2- Moderate; 3- High)

69. Is there evidence of ice build-up? 1 (Y or N)

70. Debris and Ice Comments:
(Yor $N)$ 66. Where? $\mathbf{N}$

68. Capture Efficiency 2

(1- Upstream; 2- At bridge; 3-Both)

Ice Blockage Potential $\mathbf{N}$
(1- Low; 2- Moderate; 3- High)

(1-Low; 2- Moderate; 3- High)

\section{1}

\begin{tabular}{|l|c|c|c|c|c|c|c|c|}
\hline Abutments & $\begin{array}{c}\text { 71. Attack } \\
\angle \text { (BF) }\end{array}$ & $\begin{array}{c}\text { 72. Slope } \angle \\
\text { (Qmax) }\end{array}$ & $\begin{array}{c}\text { 73. Toe } \\
\text { loc. (BF) }\end{array}$ & $\begin{array}{c}\text { 74. Scour } \\
\text { Condition }\end{array}$ & $\begin{array}{c}\text { 75. Scour } \\
\text { depth }\end{array}$ & $\begin{array}{c}\text { 76. Exposure } \\
\text { depth }\end{array}$ & 77. Material & 78. Length \\
\hline LABUT & & $\mathbf{0}$ & $\mathbf{9 0}$ & $\mathbf{2}$ & $\mathbf{0}$ & - & - & $\mathbf{9 0 . 0}$ \\
\hline RABUT & $\mathbf{1}$ & $\mathbf{0}$ & $\mathbf{9 0}$ & & & $\mathbf{2}$ & $\mathbf{0}$ & $\mathbf{7 0 . 5}$ \\
\hline
\end{tabular}

Pushed: $L B$ or RB

Toe Location (Loc.): 0- even, 1- set back, 2- protrudes

Scour cond.: 0- not evident; 1- evident (comment); 2- footing exposed; 3-undermined footing; 4- piling exposed; 5- settled; 6- failed

Materials: 1- Concrete; 2- Stone masonry or drywall; 3- steel or metal; 4- wood

79. Abutment comments (eg. undermined penetration, unusual scour processes, debris, etc.):

80. Wingwalls: $\begin{array}{lllll} & & & & \\ \text { Exist? Material? } & \text { Scour } & \text { Scour } & \text { Exposure } & \text { Angle? Length? } \\ & \text { Condition? } & \text { depth? } & \text { depth? }\end{array}$ USLWW:

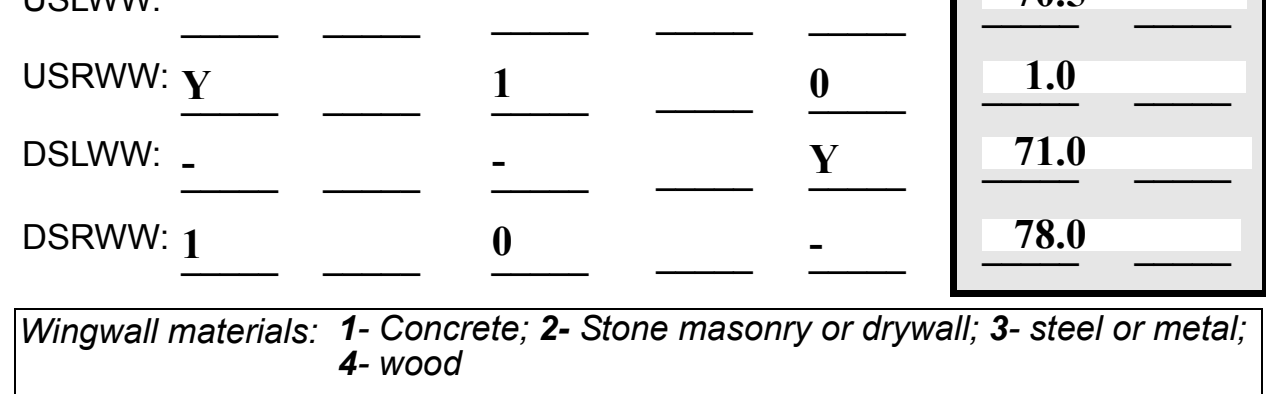

70.5

4- wood

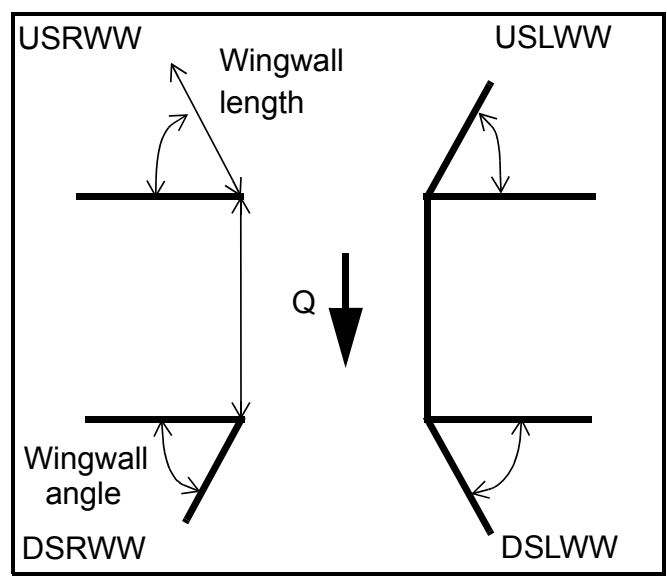

82. Bank / Bridge Protection:

\begin{tabular}{|l|l|l|l|l|l|l|l|l|}
\hline Location & USLWW & USRWW & LABUT & RABUT & LB & RB & DSLWW & DSRWW \\
\hline Type & - & $\mathbf{0}$ & $\mathbf{Y}$ & - & - & $\mathbf{1}$ & $\mathbf{1}$ & $\mathbf{1}$ \\
\hline Condition & $\mathbf{Y}$ & - & $\mathbf{1}$ & - & - & $\mathbf{1}$ & $\mathbf{1}$ & $\mathbf{1}$ \\
\hline Extent & $\mathbf{1}$ & - & $\mathbf{0}$ & $\mathbf{0}$ & $\mathbf{2}$ & $\mathbf{2}$ & $\mathbf{2}$ & - \\
\hline
\end{tabular}

Bank / Bridge protection types: 0- absent; 1- < 12 inches; 2- < 36 inches; 3- < 48 inches; 4- < 60 inches; 
83. Wingwall and protection comments (eg. undermined penetration, unusual scour processes, etc.):

-
-
-
-
-
0
-
-
1
1
2

\section{Piers:}

84. Are there piers? _ _ (Y or if $N$ type ctrl-n pr)

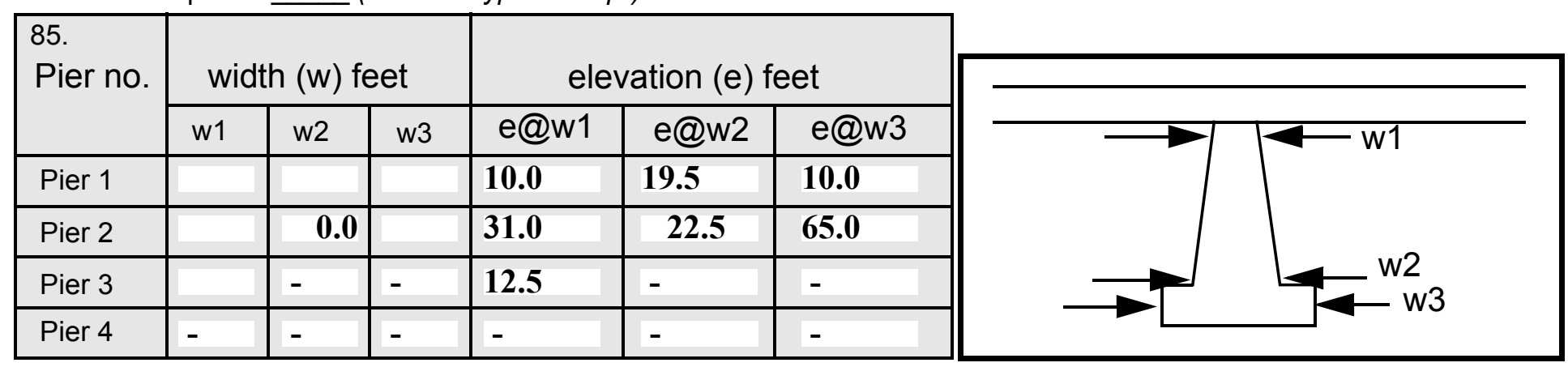

\begin{tabular}{|c|c|c|c|c|}
\hline Level 1 Pier Descr. & 1 & 2 & 3 & 4 \\
\hline 86. Location (BF) & & - & - & - \\
\hline 87. Type & & - & - & - \\
\hline 88. Material & & - & - & - \\
\hline 89. Shape & & - & - & - \\
\hline 90. Inclined? & & - & - & - \\
\hline 91. Attack $\angle(\mathrm{BF})$ & & - & - & - \\
\hline 92. Pushed & & - & - & - \\
\hline 93. Length (feet) & - & - & - & - \\
\hline 94. \# of piles & & - & - & - \\
\hline 95. Cross-members & & - & - & - \\
\hline 96. Scour Condition & & - & - & - \\
\hline 97. Scour depth & $\mathbf{N}$ & - & - & - \\
\hline 98. Exposure depth & - & - & - & - \\
\hline
\end{tabular}

LFP, LTB, LB, MCL, MCM, MCR, RB, RTB, RFP

1- Solid pier, 2- column, 3- bent

1-Wood; 2- concrete; 3- metal; 4- stone

1- Round; 2- Square; 3- Pointed

Y-yes; $N$ - no

$L B$ or $R B$

0- none; 1- laterals; 2- diagonals; 3- both

0- not evident; 1- evident (comment);

2- footing exposed; 3- piling exposed;

4- undermined footing; 5- settled; 6- failed 
99. Pier comments (eg. undermined penetration, protection and protection extent, unusual scour processes, etc.):

-
-
-
-
-
-
-
-
-

100.

\section{E. Downstream Channel Assessment}

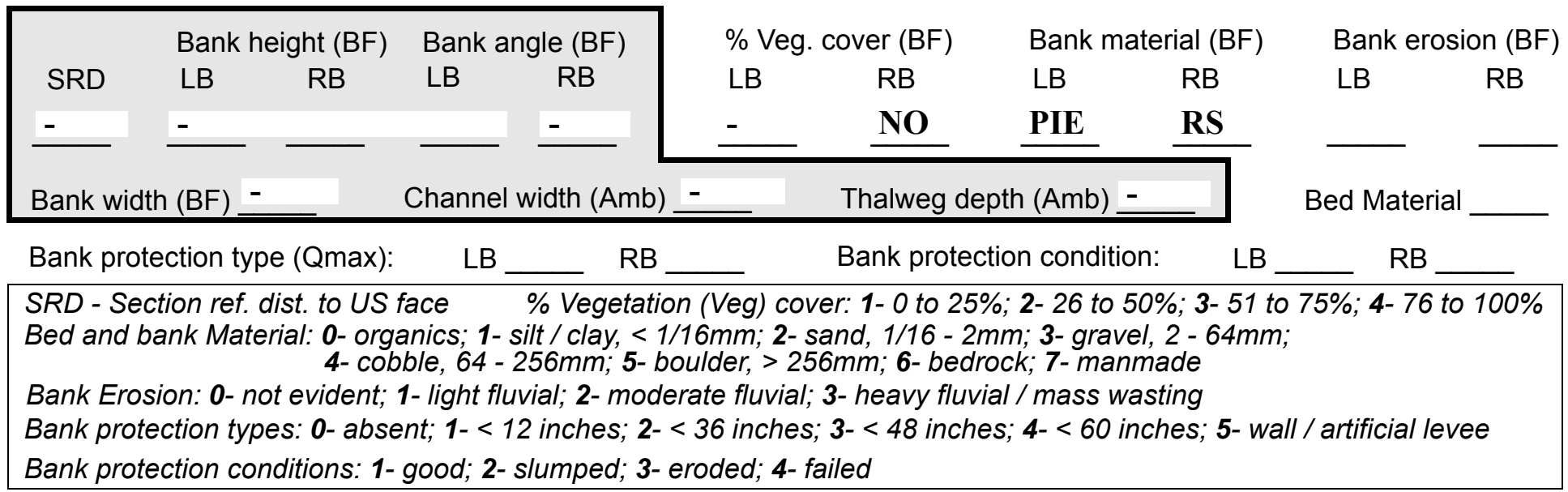

Comments (eg. bank material variation, minor inflows, protection extent, etc.):

1

3

324

634

1

1

634

2

2

1

1

The left bank protection extends from 0 feet downstream to 137 feet downstream. Where the protection ends, the bank has been well eroded. On the right bank the protection extends from 0 feet downstream to 25 feet

101. Is a drop structure present? do ( $Y$ or $N$, if $N$ type ctrl-n ds) 102. Distance: ___ feet

103. Drop: -_ feet 104. Structure material: wn (1- steel sheet pile; 2- wood pile; 3- concrete; 4- other) 105. Drop structure comments (eg. downstream scour depth):

stream where bedrock is prevalent along the bank. 
106. Point/Side bar present? (Y or N. if $N$ type ctrl-n pb)Mid-bar distance:

Mid-bar width:

Point bar extent: feet

(US, UB, DS) to feet (US, UB, DS) positioned $\underline{\mathbf{N}}$ $\%$ LB to $\%$ RB

Material: NO

Point or side bar comments (Circle Point or Side; note additional bars, material variation, status, etc.):

\section{DROP STRUCTURE}

Is a cut-bank present? ( $Y$ or if $N$ type ctrl-n $c b) \quad$ Where? (LB or $R B)$

Mid-bank distance: $\underline{\mathbf{Y}}$ Cut bank extent: 130 feet $\underline{\mathbf{1 6}}$ (US, UB, DS) to $\underline{\mathbf{5 5}}$ feet $\underline{\mathrm{DS}}$ (US, UB, DS)

Bank damage: 218 (1- eroded and/or creep; 2- slip failure; 3- block failure)

Cut bank comments (eg. additional cut banks, protection condition, etc.):

DS

0

45

34

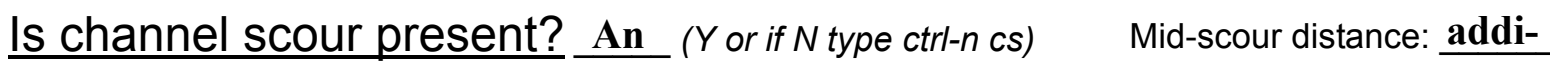
Scour dimensions: Length tiona Width $\underline{1 \text { side Depth: bar }} \quad$ Positioned exis $\%$ LB to ts $\%$ RB Scour comments (eg. additional scour areas, local scouring process, etc.):

from 0 feet downstream to 36 feet downstream. The mid-bar distance is 15 feet downstream and 11 feet wide. The bar material is cobble and it is positioned $75 \% \mathrm{LB}$ to $100 \% \mathrm{RB}$.

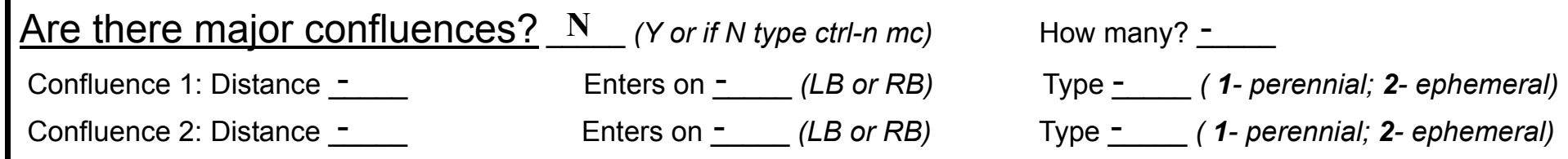
Confluence comments (eg. confluence name):

NO CUT BANKS

\section{F. Geomorphic Channel Assessment}

107. Stage of reach evolution

1- Constructed

2- Stable

3- Aggraded

4- Degraded

5- Laterally unstable

6- Vertically and laterally unstable 
108. Evolution comments (Channel evolution not considering bridge effects; See HEC-20, Figure 1 for geomorphic descriptors):

Y

128

90

7

2

70

85

On the right side of the scour hole there is bedrock. On the left side of the scour hole a point bar is present. Scour depth assumes thalweg is 1 foot.

$\mathbf{N}$ 


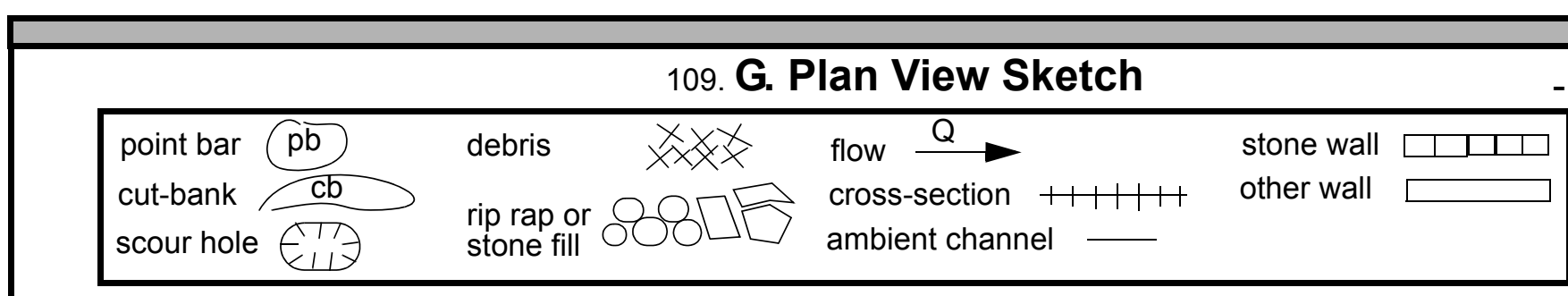


APPENDIX F:

SCOUR COMPUTATIONS 
SCOUR COMPUTATIONS

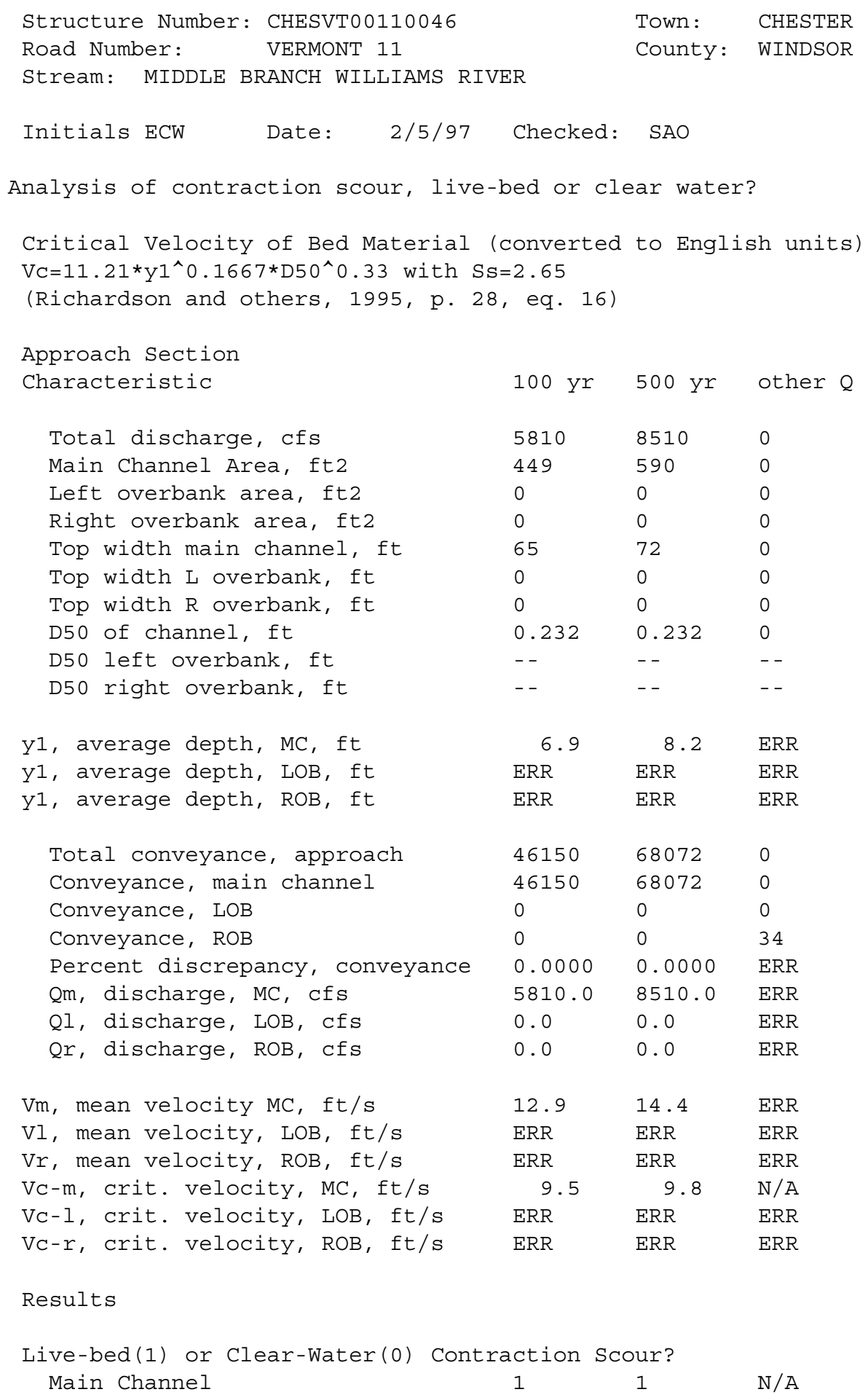




\begin{tabular}{|c|c|c|c|c|c|c|}
\hline \multicolumn{7}{|c|}{ 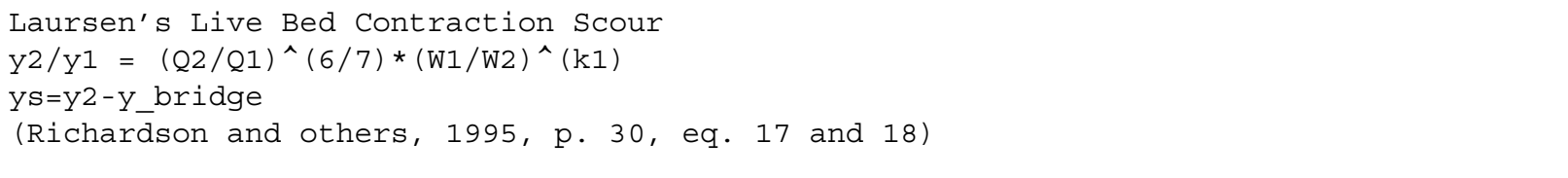 } \\
\hline & Approach & & & Bridge & & \\
\hline Characteristic & $100 \mathrm{yr}$ & $500 \mathrm{yr} O$ & Other $Q$ & $100 \mathrm{yr}$ & $500 \mathrm{yr}$ & Other $Q$ \\
\hline Q1, discharge, cfs & 5810 & 8510 & 0 & 5810 & 8510 & 0 \\
\hline Total conveyance & 46150 & 68072 & 0 & 68485 & 86860 & 0 \\
\hline Main channel conveyance & 46150 & 68072 & 0 & 68485 & 86860 & 0 \\
\hline Main channel discharge & 5810 & 8510 & $\mathrm{ERR}$ & 5810 & 8510 & $\mathrm{ERR}$ \\
\hline Area - main channel, ft2 & 449 & 590 & 0 & 567 & 695 & 0 \\
\hline (W1) channel width, ft & 65 & 72 & 0 & 70.3 & 70.3 & 0 \\
\hline (Wp) cumulative pier width, ft & 0 & 0 & 0 & 0 & 0 & 0 \\
\hline w1, adjusted bottom width(ft) & 65 & 72 & 0 & 70.3 & 70.3 & 0 \\
\hline D50, ft & 0.232 & 0.232 & 0.232 & & & \\
\hline w, fall velocity, ft/s (p. 32) & 3.94 & 3.94 & 0 & & & \\
\hline Y, ave. depth flow, ft & 6.91 & 8.19 & $\mathrm{~N} / \mathrm{A}$ & 8.07 & 9.89 & ERR \\
\hline S1, slope EGL & 0.013 & 0.013 & 0 & & & \\
\hline $\mathrm{P}$, wetted perimeter, $\mathrm{MC}$, ft & 70 & 81 & 0 & & & \\
\hline R, hydraulic Radius, ft & 6.414 & 7.284 & $\mathrm{ERR}$ & & & \\
\hline $\mathrm{V}^{*}$, shear velocity, ft/s & 1.639 & 1.746 & $\mathrm{~N} / \mathrm{A}$ & & & \\
\hline $\mathrm{V} * / \mathrm{w}$ & 0.416 & 0.443 & ERR & & & \\
\hline $\begin{array}{l}\text { Bed transport coeff., k1, }(0.59 \text { if } \\
\text { k1 }\end{array}$ & $\begin{array}{l}\mathrm{V}^{*} / \mathrm{w}<0.5 \\
0.59\end{array}$ & $\begin{array}{l}0.64 \text { if } \\
0.59\end{array}$ & $\begin{array}{l}5<\mathrm{V}^{*} / \mathrm{W}<2 \\
0\end{array}$ & 0.69 if & $V^{*} / \mathrm{w}>2.0$ & 0 p. 33$)$ \\
\hline y2, depth in contraction, ft & 6.60 & 8.31 & ERR & & & \\
\hline ys, scour depth, ft (y2-y_bridge) & -1.47 & -1.58 & $\mathrm{~N} / \mathrm{A}$ & & & \\
\hline \multicolumn{7}{|l|}{ ARMORING } \\
\hline D90 & 0.762 & 0.762 & 0.762 & & & \\
\hline D95 & 1.198 & 1.198 & 1.198 & & & \\
\hline Critical grain size,Dc, ft & 0.4481 & 0.5895 & $5 \quad \mathrm{ERR}$ & & & \\
\hline $\begin{array}{l}\text { Decimal-percent coarser than Dc } \\
\text { depth to armoring ft }\end{array}$ & $\begin{array}{l}0.209 \\
5.09\end{array}$ & $\begin{array}{l}0.181 \\
8.00\end{array}$ & $\begin{array}{l}0 \\
E R R\end{array}$ & & & \\
\hline
\end{tabular}




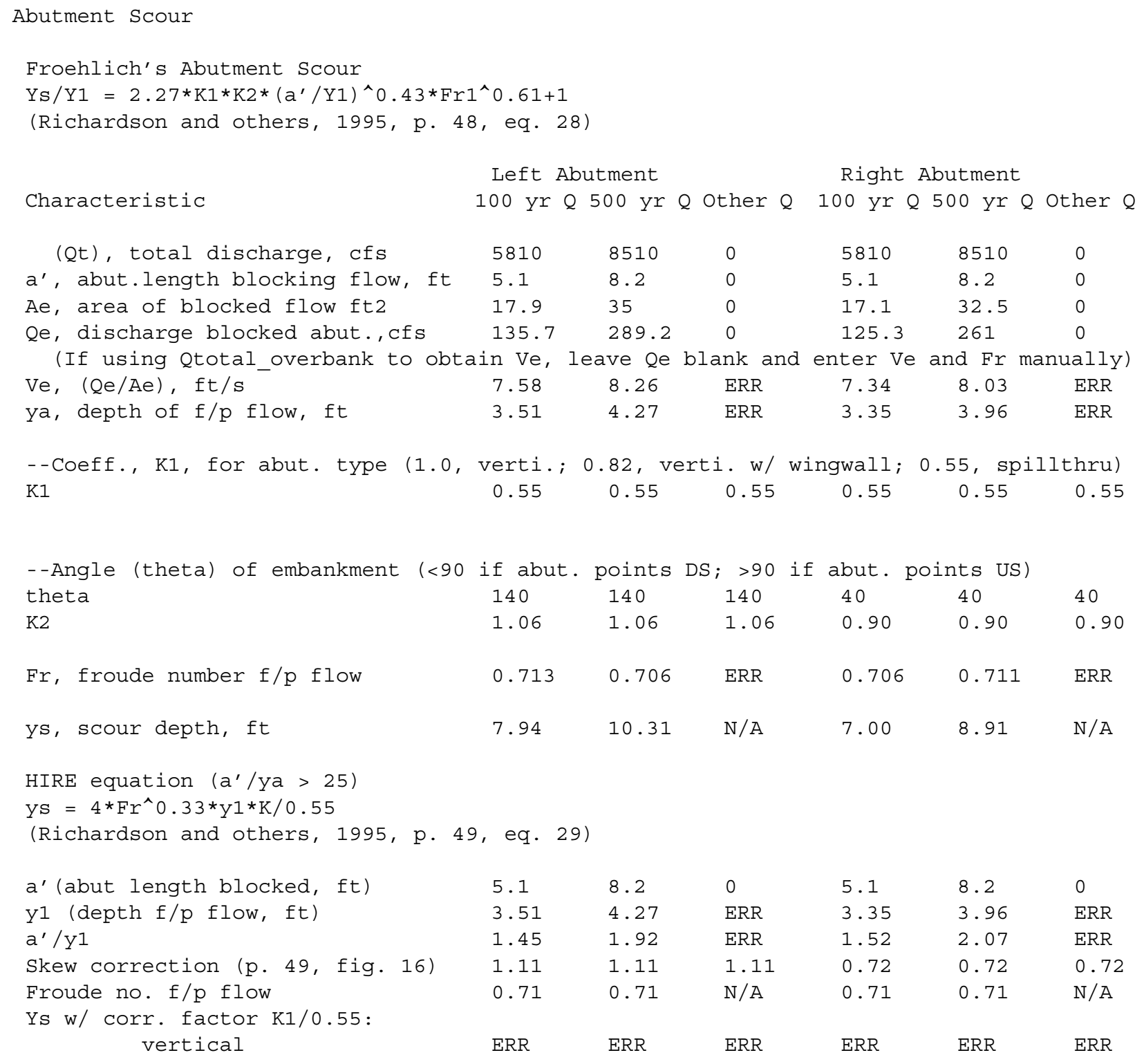




$\begin{array}{lllllll}\text { vertical w/ ww's } & \text { ERR } & \text { ERR } & \text { ERR } & \text { ERR } & \text { ERR } & \text { ERR } \\ \text { spill-through } & \text { ERR } & \text { ERR } & \text { ERR } & \text { ERR } & \text { ERR } & \text { ERR }\end{array}$

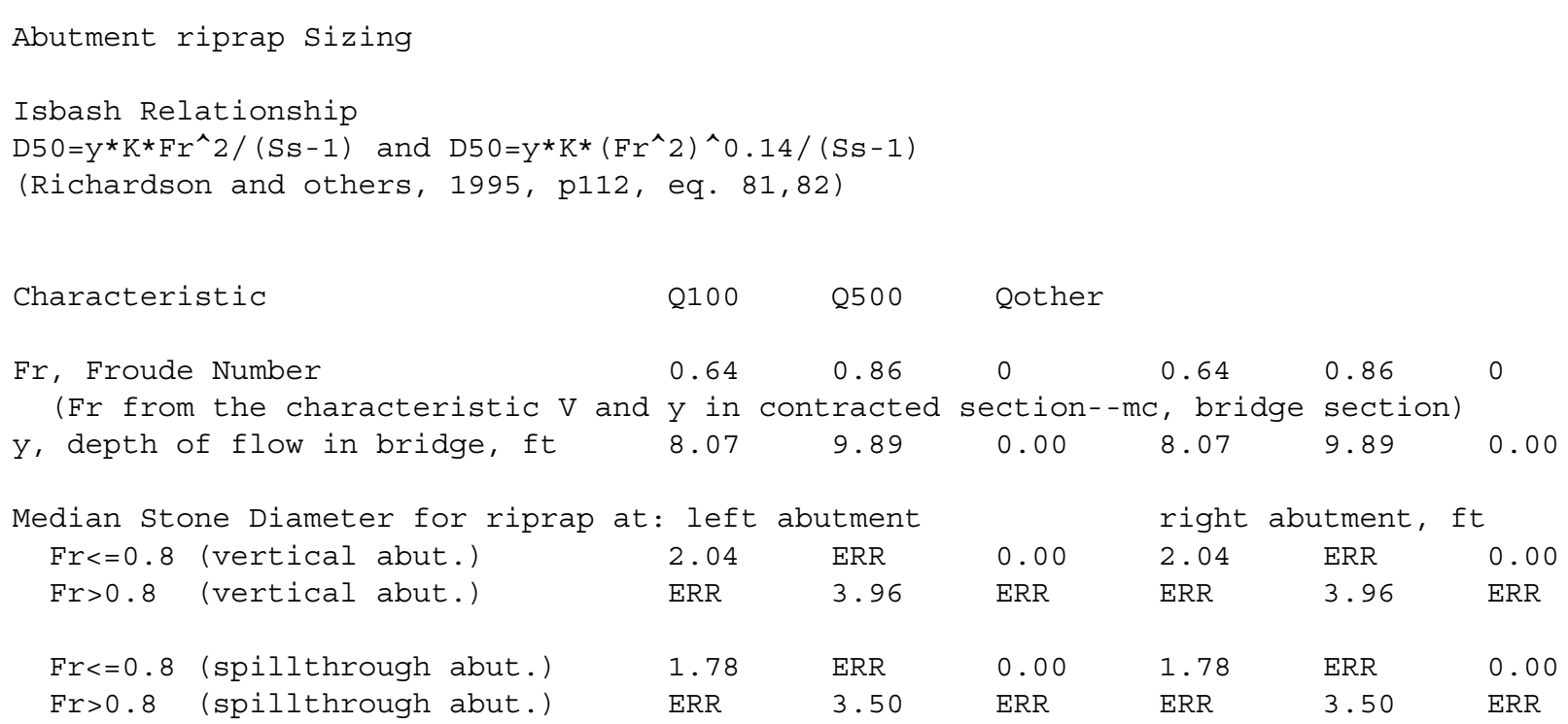

